\title{
LEVEL II SCOUR ANALYSIS FOR BRIDGE 9 (LOWETH00020009) on TOWN HIGHWAY 2, crossing the EAST BRANCH MISSISQUOI RIVER, LOWELL, VERMONT
}

U.S. Geological Survey Open-File Report 98-291

Prepared in cooperation with

VERMONT AGENCY OF TRANSPORTATION and

FEDERAL HIGHWAY ADMINISTRATION 


\section{LEVEL II SCOUR ANALYSIS FOR BRIDGE 9 (LOWETH00020009) on TOWN HIGHWAY 2, crossing the EAST BRANCH MISSISQUOI RIVER, LOWELL, VERMONT \\ By ERICK M. BOEHMLER}

U.S. Geological Survey Open-File Report 98-291

Prepared in cooperation with

VERMONT AGENCY OF TRANSPORTATION

and

FEDERAL HIGHWAY ADMINISTRATION 


\title{
U.S. DEPARTMENT OF THE INTERIOR BRUCE BABBITT, Secretary
}

\author{
U.S. GEOLOGICAL SURVEY
}

Thomas J. Casadevall, Acting Director

For additional information write to:

District Chief

U.S. Geological Survey 361 Commerce Way

Pembroke, NH 03275-3718
Copies of this report may be purchased from:

U.S. Geological Survey

Branch of Information Services

Open-File Reports Unit

Box 25286

Denver, CO 80225-0286 


\section{CONTENTS}

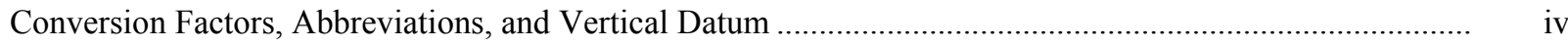

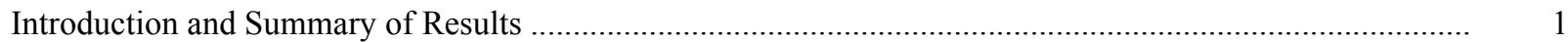

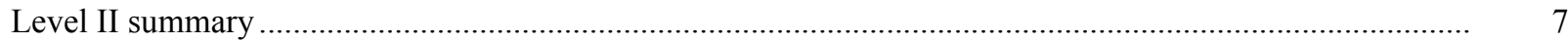

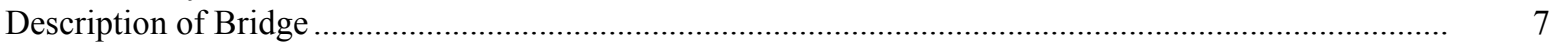

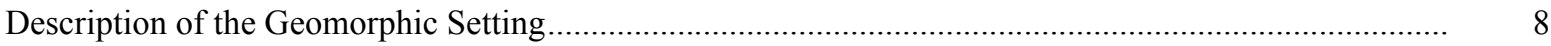

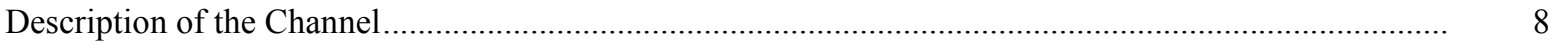

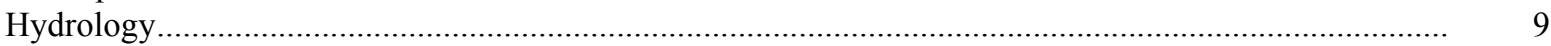

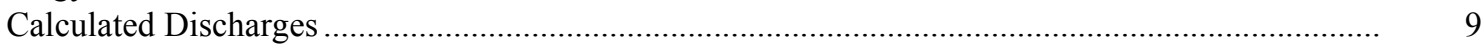

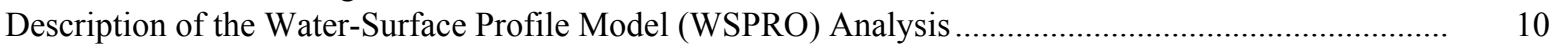

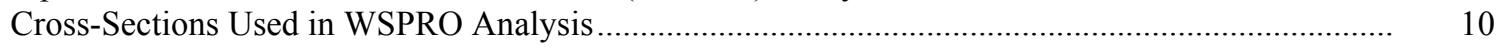

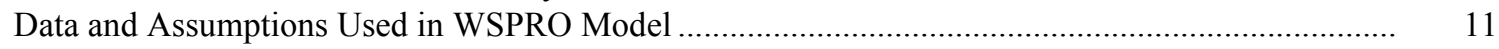

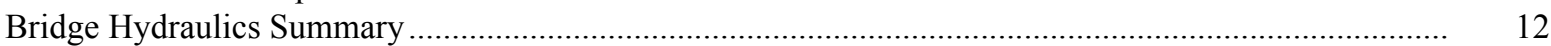

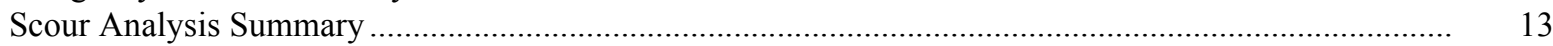

Special Conditions or Assumptions Made in Scour Analysis ..................................................... 13

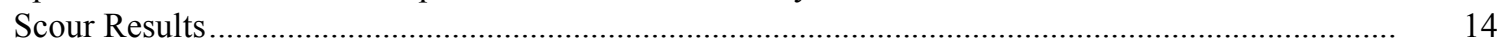

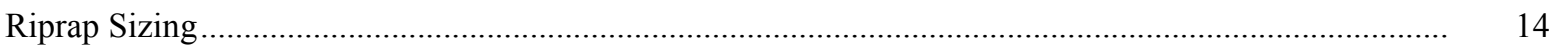

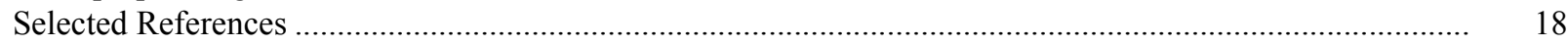

Appendices:

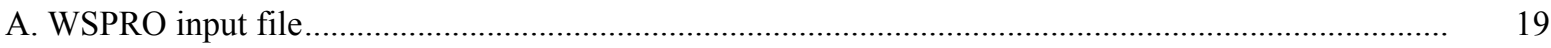

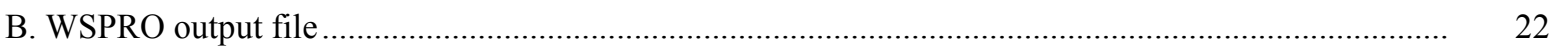

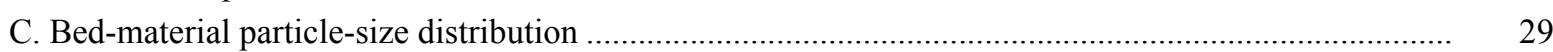

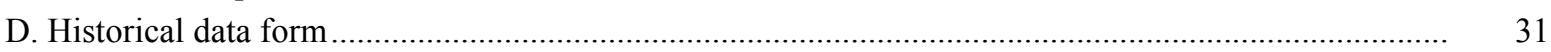

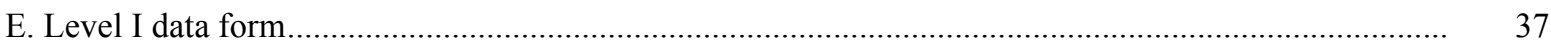

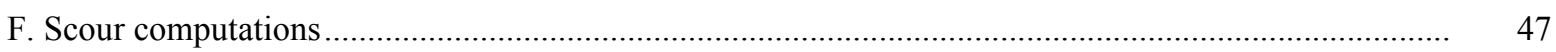

\section{FIGURES}

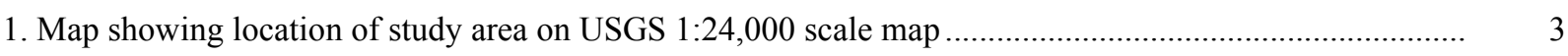

2. Map showing location of study area on Vermont Agency of Transportation town

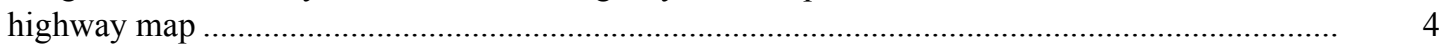

3. Structure LOWETH00020009 viewed from upstream (June 13, 1995) ............................................... 5

4. Downstream channel viewed from structure LOWETH00020009 (June 13, 1995)................................ 5

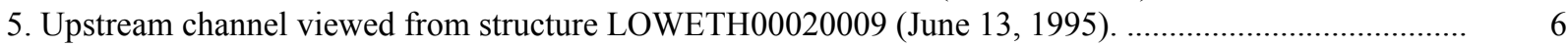

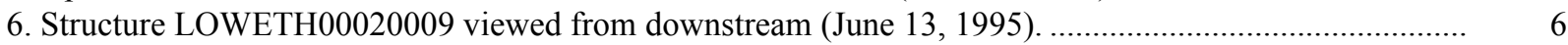

7. Water-surface profiles for the 100- and 500-year discharges at structure LOWETH00020009
on Town Highway 2, crossing the East Branch Missisquoi River, Lowell, Vermont. ......................

8. Scour elevations for the 100- and 500-year discharges at structure LOWETH00020009 on Town Highway 2, crossing the East Branch Missisquoi River, Lowell, Vermont. ................. 16

\section{TABLES}

1. Remaining footing/pile depth at abutments for the 100-year discharge at structure LOWETH00020009 on Town Highway 2, crossing the East Branch Missisquoi River,

Lowell, Vermont ....

2. Remaining footing/pile depth at abutments for the 500-year discharge at structure

LOWETH00020009 on Town Highway 2, crossing the East Branch Missisquoi River,

Lowell, Vermont 


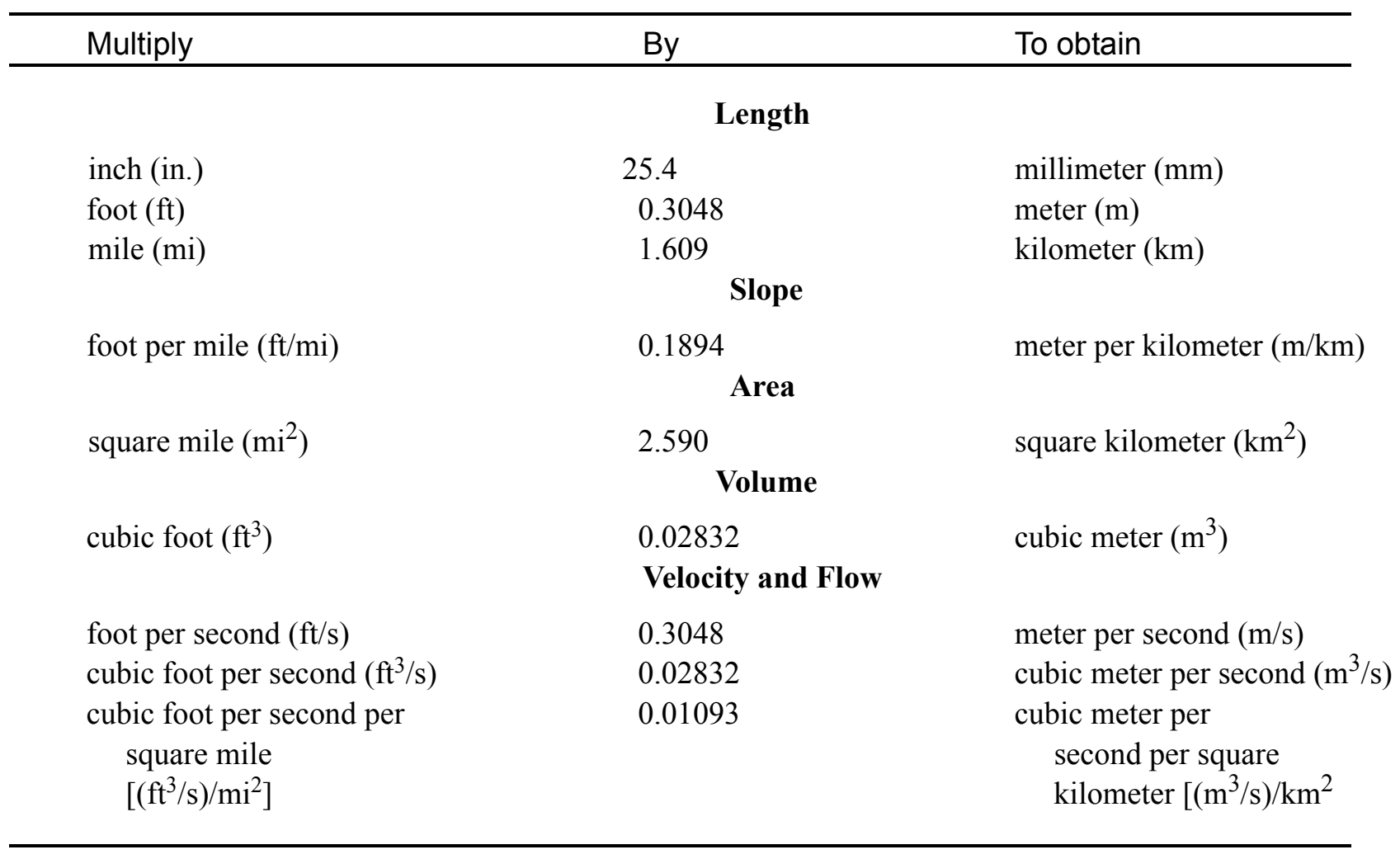

\section{OTHER ABBREVIATIONS}

$\begin{array}{lrlr}\mathrm{BF} & \begin{array}{r}\text { bank full } \\ \mathrm{cfs}\end{array} & \text { LWW } & \text { left wingwall } \\ \mathrm{D}_{50} & \begin{array}{r}\text { cubic feet per second } \\ \text { maximum }\end{array} \\ \mathrm{DS} & \text { Max } & \text { main channel } \\ \mathrm{elev} & \text { downstream } & \text { RAB } & \text { riameter of bed material } \\ \mathrm{f} / \mathrm{p} & \text { elevation } & \text { RABUT } & \text { floce of right abutment } \\ \mathrm{ft}^{2} & \text { flood plain } & \text { RB } & \text { right bank } \\ \mathrm{ft} / \mathrm{ft} & \text { square feet } & \text { ROB } & \text { right overbank } \\ \mathrm{FEMA} & \text { feet per foot } & \text { RWW } & \text { right wingwall } \\ \text { FHWA } & \text { Federal Emergency Management Agency } & \text { TH } & \text { town highway } \\ \text { JCT } & \text { Federal Highway Administration } & \text { UB } & \text { under bridge } \\ \text { LAB } & \text { junction } & \text { US } & \text { upstream } \\ \text { LABUT } & \text { left abutment } & \text { USGS } & \text { United States Geological Survey } \\ \text { LB } & \text { face of left abutment } & \text { VTAOT } & \text { Vermont Agency of Transportation } \\ \text { LOB } & \text { left bank } & \text { WSPRO } & \text { water-surface profile model } \\ & \text { left overbank } & \text { yr } & \text { year }\end{array}$

In this report, the words "right" and "left" refer to directions that would be reported by an observer facing downstream. Sea level: In this report, "sea level" refers to the National Geodetic Vertical Datum of 1929-- a geodetic datum derived from a general adjustment of the first-order level nets of the United States and Canada, formerly called Sea Level Datum of 1929.

In the appendices, the above abbreviations may be combined. For example, USLB would represent upstream left bank. 


\title{
LEVEL II SCOUR ANALYSIS FOR BRIDGE 9 (LOWETH00020009) ON TOWN HIGHWAY 2, CROSSING THE EAST BRANCH MISSISQUOI RIVER, LOWELL, VERMONT
}

\author{
By Erick M. Boehmler
}

\section{INTRODUCTION AND SUMMARY OF RESULTS}

This report provides the results of a detailed Level II analysis of scour potential at structure LOWETH00020009 on Town Highway 2 crossing the East Branch Missisquoi River, Lowell, Vermont (figures 1-8). A Level II study is a basic engineering analysis of the site, including a quantitative analysis of stream stability and scour (FHWA, 1993). Results of a Level I scour investigation also are included in appendix E of this report. A Level I investigation provides a qualitative geomorphic characterization of the study site. Information on the bridge, gleaned from Vermont Agency of Transportation (VTAOT) files, was compiled prior to conducting Level I and Level II analyses and is found in appendix D.

The site is in the Green Mountain section of the New England physiographic province in north-central Vermont. The $13.5-\mathrm{mi}^{2}$ drainage area is in a predominantly rural and forested basin. In the vicinity of the study site, the surface cover consists of shrubs and brushland, pasture, and forest.

In the study area, the East Branch Missisquoi River has a sinuous channel with a slope of approximately $0.005 \mathrm{ft} / \mathrm{ft}$, an average channel top width of $46 \mathrm{ft}$ and an average bank height of $4 \mathrm{ft}$. The predominant channel bed material is gravel with a median grain size $\left(\mathrm{D}_{50}\right)$ of $33.2 \mathrm{~mm}(0.109 \mathrm{ft})$. The geomorphic assessment at the time of the site visits on June 13 and June 15,1995 , indicated that the reach was laterally unstable. Cut-banks with slip and block failure of bank material, heavy bank erosion, and coincident point bars were evident in the reach near this site.

The Town Highway 2 crossing of the East Branch Missisquoi River is a 33-foot-long, twolane bridge consisting of one 30-foot concrete T-beam span (Vermont Agency of Transportation, written communication, March 7, 1995). The opening length of the structure parallel to the bridge face is 29.6 feet. The bridge is supported by vertical, concrete abutments with wingwalls. The channel is skewed approximately 10 degrees to the opening while the opening-skew-to-roadway is zero degrees. 
A scour hole $1 \mathrm{ft}$ deeper than the mean thalweg depth was observed along the left abutment during the Level I assessment. There were no scour protection measures evident at the site. Additional details describing conditions at the site are included in the Level II Summary and appendices $\mathrm{D}$ and $\mathrm{E}$.

Scour depths and recommended rock rip-rap sizes were computed using the general guidelines described in Hydraulic Engineering Circular 18 (Richardson and others, 1995) for the 100- and 500-year discharges. In addition, the incipient roadway-overtopping discharge was determined and analyzed as another potential worst-case scour scenario. Total scour at a highway crossing is comprised of three components: 1) long-term streambed degradation; 2) contraction scour (due to accelerated flow caused by a reduction in flow area at a bridge) and; 3) local scour (caused by accelerated flow around piers and abutments). Total scour is the sum of the three components. Equations are available to compute depths for contraction and local scour and a summary of the results of these computations follows.

Contraction scour for all modelled flows ranged from 1.9 to 3.2 feet. The worst-case contraction scour occurred at the 500-year discharge. Abutment scour ranged from 5.3 to 11.3 feet at the left abutment and from 13.3 to 15.6 feet at the right abutment. The worstcase abutment scour occurred at the 100-year discharge for the left abutment and at the 500year discharge for the right abutment. Additional information on scour depths and depths to armoring are included in the section titled "Scour Results". Scoured-streambed elevations, based on the calculated scour depths, are presented in tables 1 and 2. A cross-section of the scour computed at the bridge is presented in figure 8. Scour depths were calculated assuming an infinite depth of erosive material and a homogeneous particle-size distribution.

It is generally accepted that the Froehlich equation (abutment scour) gives "excessively conservative estimates of scour depths" (Richardson and others, 1995, p. 47). Usually, computed scour depths are evaluated in combination with other information including (but not limited to) historical performance during flood events, the geomorphic stability assessment, existing scour protection measures, and the results of the hydraulic analyses. Therefore, scour depths adopted by VTAOT may differ from the computed values documented herein. 


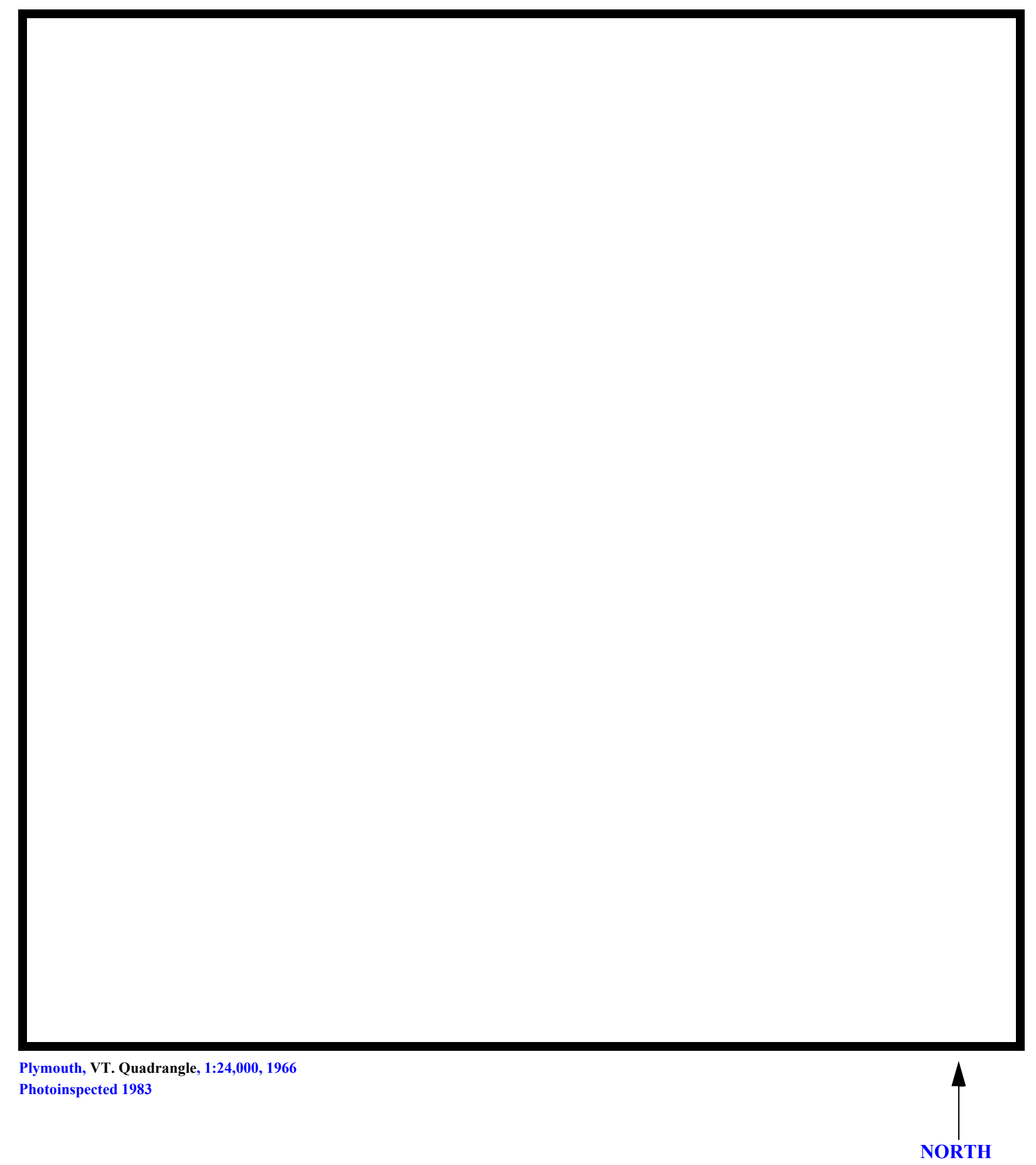

Figure 1. Location of study area on USGS 1:24,000 scale map. 
Figure 2. Location of study area on Vermont Agency of Transportation town highway map. 

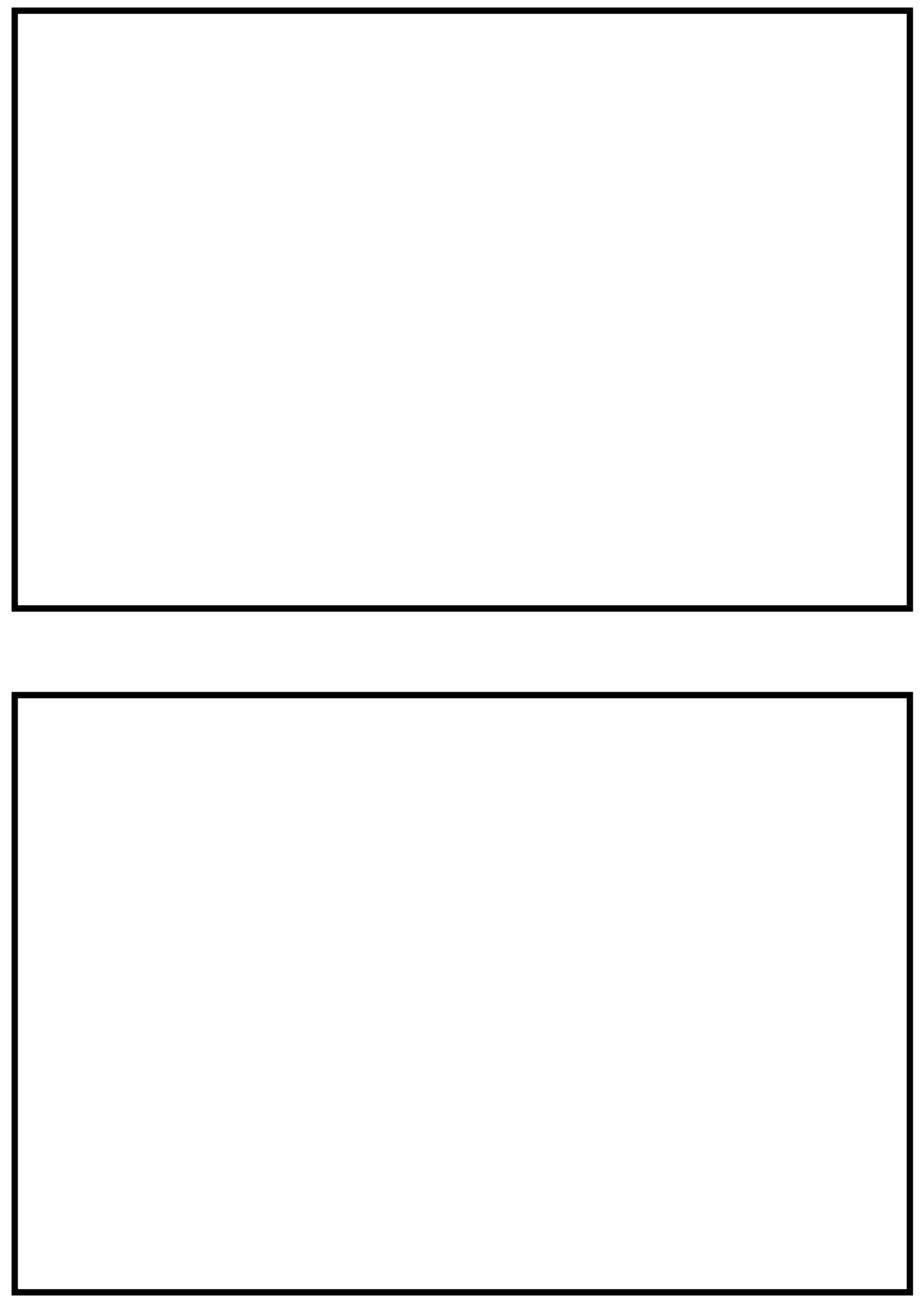

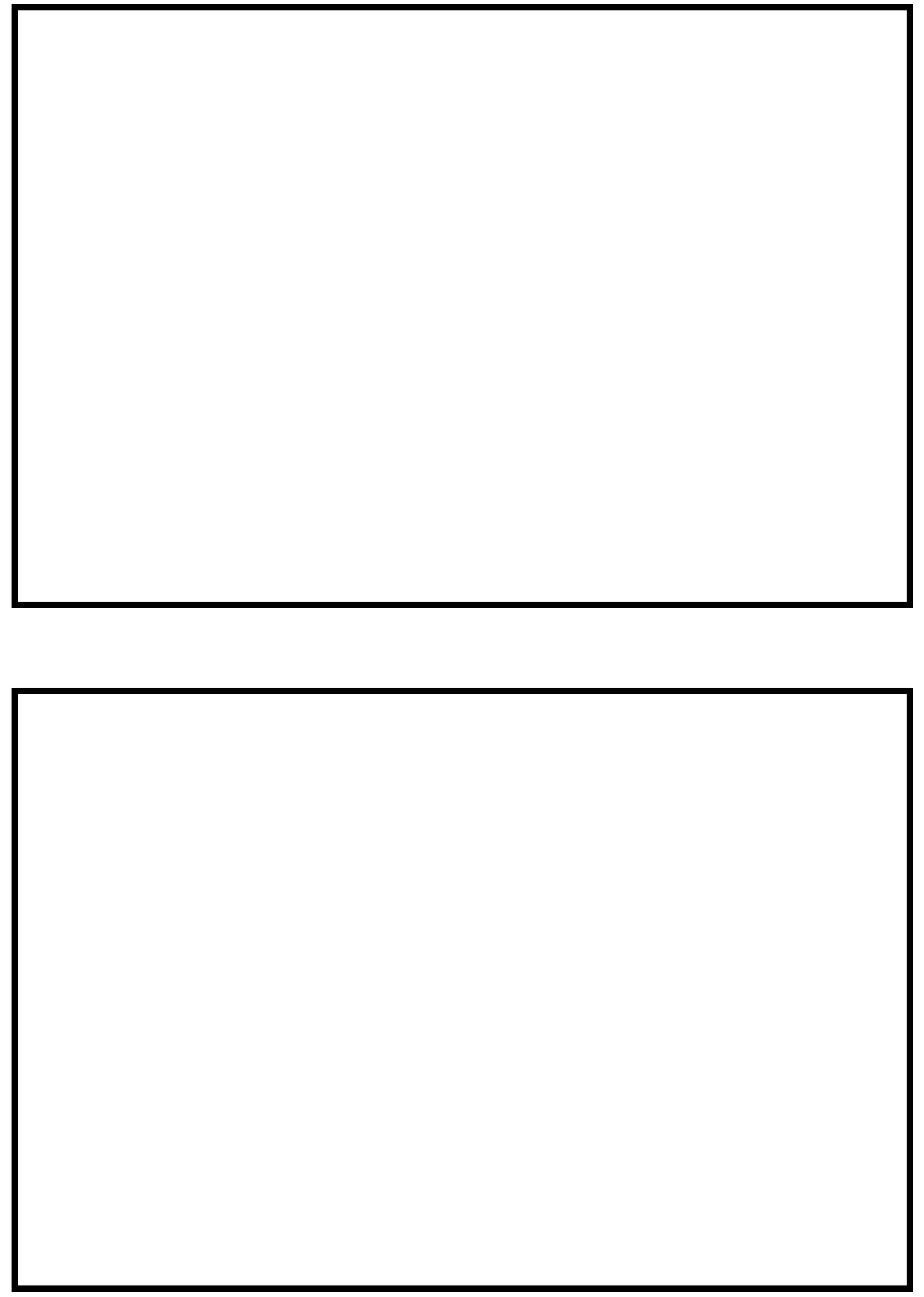


\section{LEVEL II SUMMARY}

\begin{tabular}{llllll} 
& Structure Number & LOWETH00020009 & & \multicolumn{3}{c}{ East Branch Missisquoi River } \\
& Stream & & & \\
County & Orleans & Road & TH 2 & District & 9
\end{tabular}

\section{Description of Bridge}

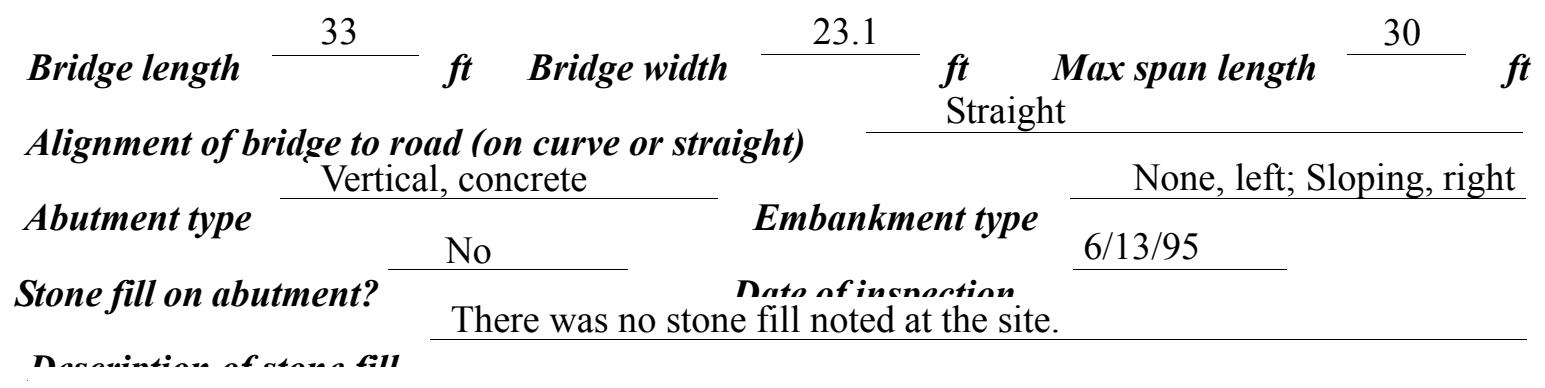

Abutments and wingwalls are concrete. There is a one

foot deep scour hole along the entire length of the left abutment and it's wingwalls.

\section{Yes}

Is bridge skewed to flood flow according to Yes 'survey? Angle

There is a moderate channel bend in the upstream reach. The scour hole has developed in the location where the flow impacts the left abutment and wingwalls

Debris accumulation on bridge at time of Level I or Level II site visit:

Date of insnortion $6 / 13 / 95$

Level I

$$
6 / 15 / 95
$$

Level II

\section{Percent of rhominal blocked inorizontally}

0
10

banks and the channel is laterally unstable.

Potential for debris

A large debris jam (perhaps a remnant beaver dam) was noted approximately 140 feet upstream Doscriho any, fonturos noar ar at tho hridoo that mav, affort flow, (includo ohsorvation dato) of the site across the entire channel on $6 / 13 / 1995$. 


\section{Description of the Geomorphic Setting}

General topography The channel is located in a moderate relief valley setting with a narrow, irregular flood plain and steep to moderately sloping valley walls.

Geomorphic conditions at bridge site: downstream (DS), upstream (US)

Date of inspection $\quad 6 / 13 / 95$

DS left: $\quad$ Moderately sloping channel bank to a flood plain.

DS right: $\quad$ Moderately sloping channel bank to a flood plain.

US left: $\quad$ Steep channel bank to a flood plain.

US right: $\quad$ Moderately sloping channel bank to a flood plain.

\section{Description of the Channel}

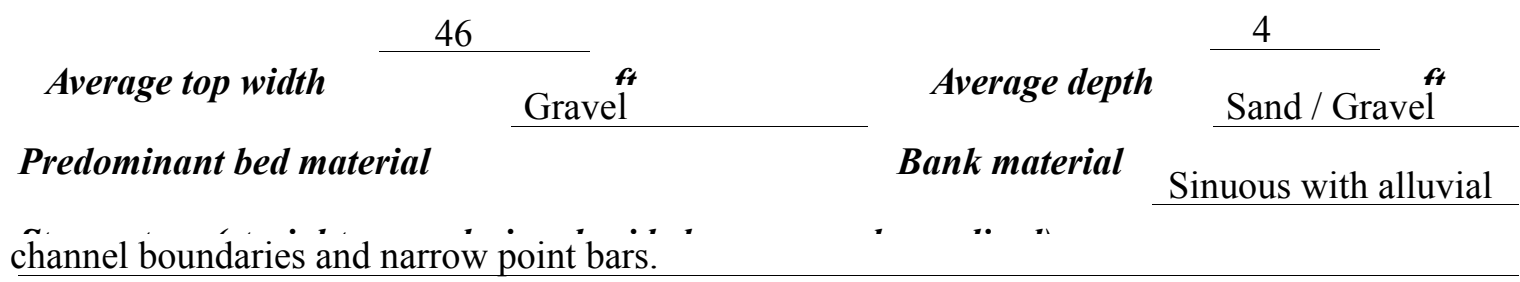

$6 / 15 / 95$

Vegetative co ${ }^{1}$ Trees, shrubs, and brush with short grass on the flood plain.

DS left: $\quad$ Shrubs and brush with a few trees.

DS right: $\quad$ Trees with some shrubs

US left: $\quad$ Shrubs and brush with a few trees.

US right:

No

Do banks appear stable? There are cut banks and point bars noted in the reach at the time of the assessment on 6/13/95. Slip and block failure of the bank material was noted at the cut banks.
date of observation. Most trees on the immediate banks in the vicinity of cut banks, particularly in the upstream reach, were leaning over the channel.

The assessment of

6/15/95 noted flow conditions, which overtop the left bank upstream, may be obstructed by piles Describe any obstructions in channel and date of observation.

of wood chips, sand and gravel, or other material stockpiled by the town in this location. 


\section{Hydrology}

Drainage area $\stackrel{13.5}{\mathrm{mi}^{2}}$

Percentage of drainage area in physiographic provinces: (approximate)

Physiographic province/section

New England / Green Mountain
Percent of drainage area 100

Is drainage area considered rural or urban? — Rural _ Describe any significant urbanization:

Yes

Is there a USGS gage on the stream of interest?

Missisquoi River near North Troy, VT

USGS gage description

04293000

USGS gage number

131

Gage drainage area

$m i^{2}$

No

Is there a lake/p _

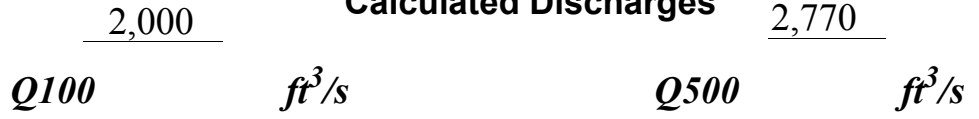

The 100- and 500-year discharges are based on

discharge frequency curves computed by use of several empirical methods and extrapolated to the 500-year event. The discharges selected were central in the range defined by several empirical methods (Benson, 1962; Johnson and Tasker, 1974; FHWA, 1983; Potter, 1957a\&b;

Talbot, 1887). 


\section{Description of the Water-Surface Profile Model (WSPRO) Analysis}

Datum for WSPRO analysis (USGS survey, sea level, VTAOT plans) ～USGS survey

Datum tie between USGS survey and VTAOT plans $\quad$ Subtract 298.0 feet from the

USGS arbitrary survey datum to obtain the VTAOT plans' datum to the nearest 0.5 feet.

Description of reference marks used to determine USGS datum. $\quad$ RM1 is a chiseled " $X$ "

on top of the left end of the concrete curb on the downstream side of the bridge (elev. 500.43

feet, arbitrary survey datum). RM2 is a chiseled " $\mathrm{X}$ " on top of the right end of the concrete curb

on the upstream side of the bridge. (elev. 500.49 feet, arbitrary survey datum).

\section{Cross-Sections Used in WSPRO Analysis}

\begin{tabular}{cccl}
\hline${ }^{1}$ Cross-section & $\begin{array}{c}\text { Section } \\
\text { Reference } \\
\text { Distance } \\
\text { (SRD) in feet }\end{array}$ & $\begin{array}{c}{ }^{2} \text { Cross-section } \\
\text { development }\end{array}$ & \multicolumn{1}{c}{ Comments } \\
\hline EXITX & -26 & 1 & Exit section \\
FULLV & 0 & 5 & $\begin{array}{l}\text { Downstream Full-valley sec- } \\
\text { tion (EXITX overbank points } \\
\text { with BRIDG channel points) }\end{array}$ \\
BRIDG & 0 & 1 & Bridge section \\
RDWAY & 13 & 1 & Road Grade section \\
APPRO & 53 & 1 & Approach section \\
\hline
\end{tabular}

${ }^{1}$ For location of cross-sections see plan-view sketch included with Level I field form, Appendix E. For more detail on how cross-sections were developed see WSPRO input file. 


\section{Data and Assumptions Used in WSPRO Model}

Hydraulic analyses of the reach were done by use of the Federal Highway Administration's WSPRO step-backwater computer program (Shearman and others, 1986, and Shearman, 1990). The analyses reported herein reflect conditions existing at the site at the time of the study. Furthermore, in the development of the model it was necessary to assume no accumulation of debris or ice at the site. Results of the hydraulic model are presented in the Bridge Hydraulic Summary, appendix B, and figure 7.

Channel roughness factors (Manning's “ $n$ ”) used in the hydraulic model were estimated using field inspections at each cross section following the general guidelines described by Arcement and Schneider (1989). Final adjustments to the values were made during the modelling of the reach. Channel " $n$ " values for the reach ranged from 0.040 to 0.055 , and overbank " $n$ " values ranged from 0.040 to 0.085 .

Normal depth at the exit section (EXITX) was assumed as the starting water surface. This depth was computed by use of the slope-conveyance method outlined in the user's manual for WSPRO (Shearman, 1990). The slope used was $0.0053 \mathrm{ft} / \mathrm{ft}$, which was estimated from surveyed thalweg points in the channel downstream of the bridge.

The approach section (APPRO) was surveyed one bridge length upstream of the upstream face as recommended by Shearman and others (1986). This location provides a consistent method for determining scour variables. 


\section{Bridge Hydraulics Summary}

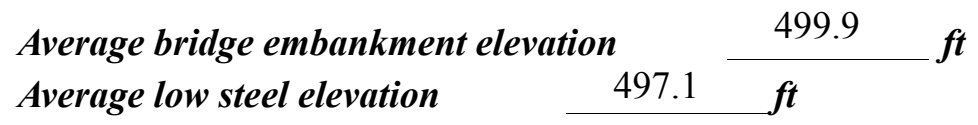

100-year discharge $\quad 2,000 \quad \mathrm{ft}^{3} / \mathrm{s}$

Water-surface elevation in bridge opening $\quad 497.2 \quad f t$

Road overtopping? ___ Yes Discharge over road __ $30 \quad \mathrm{ft}^{3} / \mathrm{s}$

Area of flow in bridge opening $\quad 209 \quad \mathrm{ft}^{2}$

Average velocity in bridge opening $\quad 9.4 \quad \mathrm{ft} / \mathrm{s}$

Maximum WSPRO tube velocity at bridge $11.5 \mathrm{ft} / \mathrm{s}$

Water-surface elevation at Approach section with bridge 499.6

$\begin{array}{lr}\text { Water-surface elevation at Approach section without bridge } & 495.0\end{array}$

Amount of backwater caused by bridge $\quad 4.6 \quad$ it

500-year discharge $\quad 2,770 \quad \mathrm{ft}^{3} / \mathrm{s}$

Water-surface elevation in bridge opening $\quad 497.2 \mathrm{ft}$

Road overtopping? ___ Yes Discharge over road __ $663 \mathrm{ft}^{3} / \mathrm{s}$

Area of flow in bridge opening $\quad 209 \quad \mathrm{ft}^{2}$

Average velocity in bridge opening $10.1 \mathrm{ft} / \mathrm{s}$

Maximum WSPRO tube velocity at bridge 12.4 's

Water-surface elevation at Approach section with bridge 500.2

Water-surface elevation at Approach section without bridge -495.3

Amount of backwater caused by bridge 4.9 .t

Incipient overtopping discharge $\quad 1,880 \mathrm{ft}^{3} / \mathrm{s}$

Water-surface elevation in bridge opening $497.2 \quad t$

\begin{tabular}{llll} 
Area of flow in bridge opening & 209 & $\boldsymbol{f t}^{2}$ \\
\cline { 2 - 3 } Average velocity in bridge opening & $9.0 \quad \mathrm{ft} / \mathrm{s}$
\end{tabular}

Maximum WSPRO tube velocity at bridge $11.0 \mathrm{ft} / \mathrm{s}$

Water-surface elevation at Approach section with bridge

Water-surface elevation at Approach section without bridge

499.2

Amount of backwater caused by bridge $\quad 4.3$.t 


\section{Scour Analysis Summary}

\section{Special Conditions or Assumptions Made in Scour Analysis}

Scour depths were computed using the general guidelines described in Hydraulic Engineering Circular 18 (Richardson and others, 1995). Scour depths were calculated assuming an infinite depth of erosive material and a homogeneous particle-size distribution. The results of the scour analyses for the 100- and 500-year discharges are presented in tables 1 and 2 and the scour depths are shown graphically in figure 8 .

At this site, each discharge resulted in unsubmerged orifice flow. Contraction scour at bridges with orifice flow is best estimated by use of the Chang pressure-flow scour equation (oral communication, J. Sterling Jones, October 4, 1996). Thus, contraction scour was computed by use of the Chang equation (Richardson and others, 1995, p. 145-146). Results of this analysis are presented in figure 8 and tables 1 and 2.

Additional estimates of contraction scour also were computed by use of Laursen's clear-water scour equation and the Umbrell pressure-flow equation (Richardson and others, 1995, p. 144). Results from these computations are presented in appendix F. Furthermore, contraction scour was computed by substituting alternative estimates for the depth of flow at the downstream bridge face in the contraction scour equations. Results with respect to these substitutions also are provided in appendix F.

Abutment scour was computed by use of the Froehlich equation (Richardson and others, 1995, p. 48, equation 28) for the left abutment. Variables for the Froehlich equation include the Froude number of the flow approaching the embankments, the length of the embankment blocking flow, and the depth of flow approaching the embankment less any roadway overtopping.

Scour at the right abutment was computed by use of the HIRE equation (Richardson and others, 1995, p. 49, equation 29) because the HIRE equation is recommended when the length to depth ratio of the embankment blocking flow exceeds 25 . The variables used by the HIRE abutment-scour equation are defined the same as those defined for the Froehlich abutment-scour equation. 


\section{Scour Results}

\section{0-yr discharge 500-yr discharge}

Contraction scour:

(Scour depths in feet)

Main channel

Live-bed scour

Clear-water scour

Depth to armoring

Left overbank

Right overbank

Local scour:

Abutment scour

Left abutment

11.3

5.3

8.5

14.0

15.6

13.3

Right abutment

Pier scour

Pier 1

Pier 2

Pier 3

\section{Abutments:}

Left abutment

Right abutment

Piers:

Pier 1

Pier 2

\section{Riprap Sizing}

Incipient overtopping 100-yr discharge 500-yrdischarge discharge

2.0

2.0

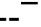

$--$

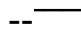
( $D_{50}$ in feet)

$2.2 \quad 2.0$

$2.2 \quad 2.0$

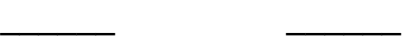

$--$
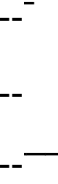


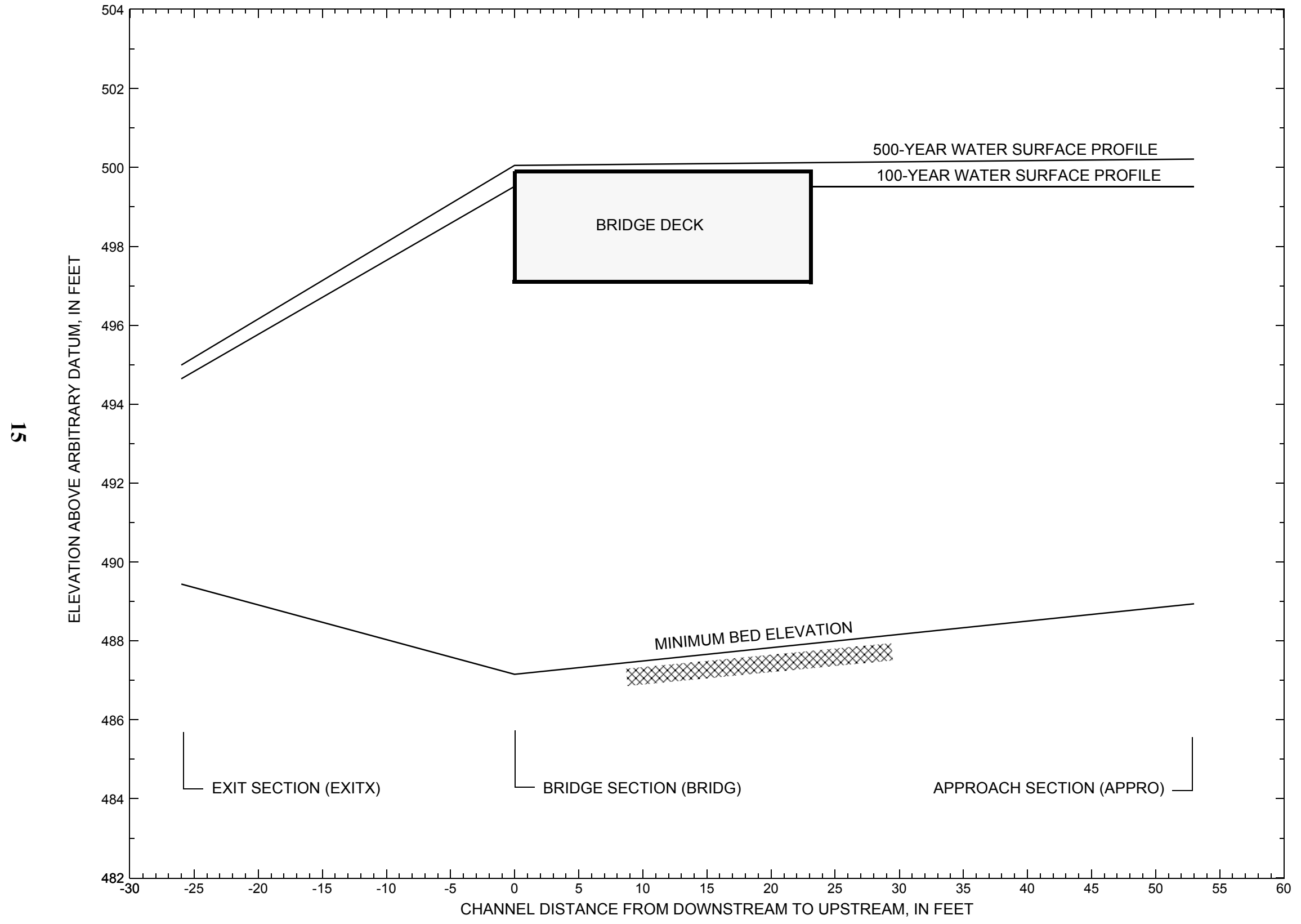

Figure 7. Water-surface profiles for the 100- and 500-year discharges at structure LOWETH00020009 on Town Highway 2, crossing East Branch Missisquoi River, Lowell, Vermont. 


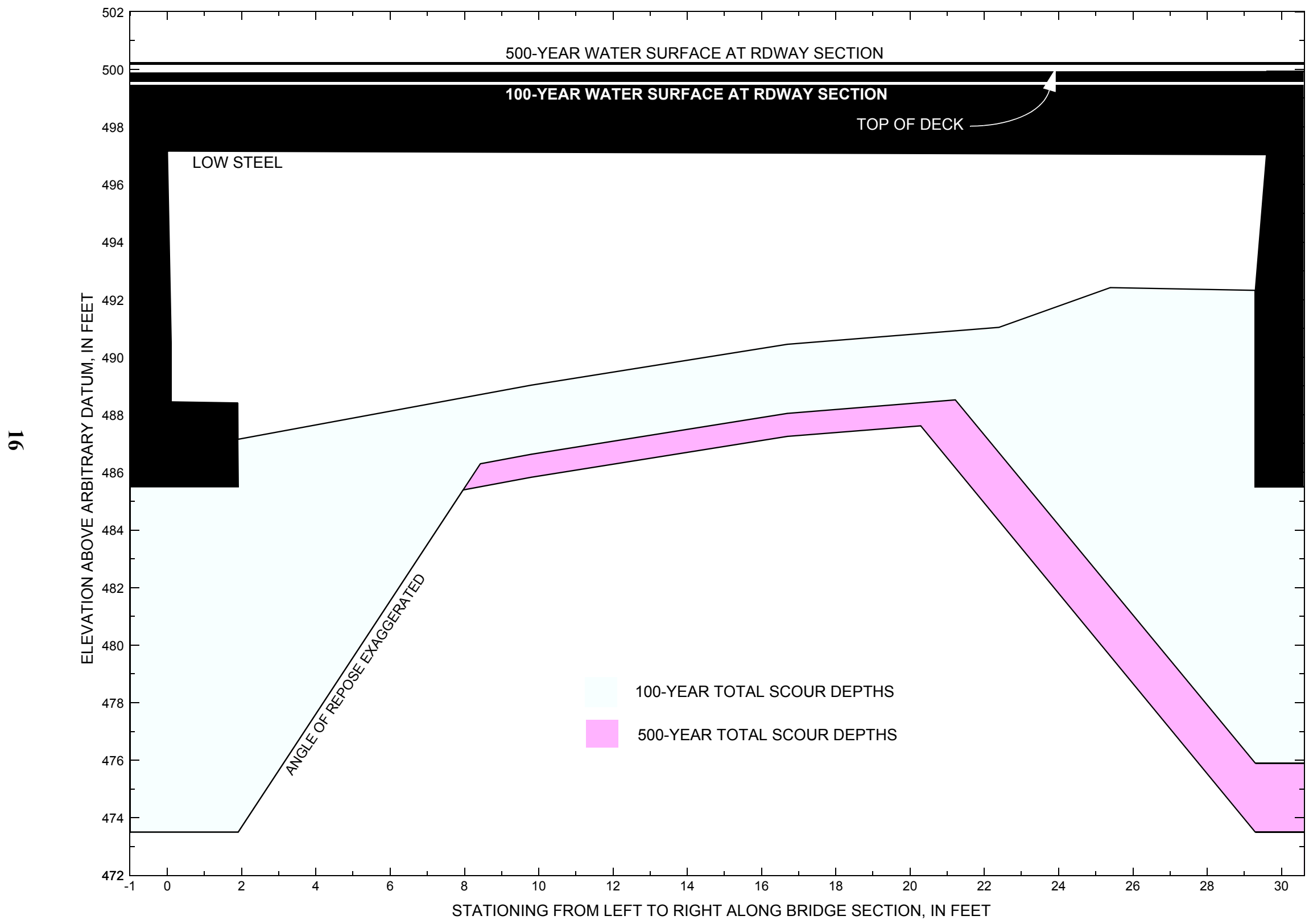

Figure 8. Scour elevations for the 100- and 500-year discharges at structure LOWETH00020009 on Town Highway 2, crossing East Branch Missisquoi River, Lowell, Vermont. 
Table 1. Remaining footing/pile depth at abutments for the 100-year discharge at structure LOWETH00020009 on Town Highway 2, crossing East Branch Missisquoi River, Lowell, Vermont.

[VTAOT, Vermont Agency of Transportation; --,no data]

\begin{tabular}{|c|c|c|c|c|c|c|c|c|c|c|c|}
\hline Description & Station $^{1}$ & $\begin{array}{l}\text { VTAOT } \\
\text { Bridge seat } \\
\text { elevation } \\
\text { (feet) }\end{array}$ & $\begin{array}{c}\text { Surveyed } \\
\text { minimum } \\
\text { low-chord } \\
\text { elevation } \\
\text { (feet) }\end{array}$ & $\begin{array}{l}\text { Bottom of } \\
\text { footing } \\
\text { elevation } \\
\text { (feet) }\end{array}$ & $\begin{array}{l}\text { Channel } \\
\text { elevation at } \\
\text { abutment/ } \\
\text { pier }^{2} \\
\text { (feet) }\end{array}$ & $\begin{array}{l}\text { Contraction } \\
\text { scour depth } \\
\text { (feet) }\end{array}$ & $\begin{array}{l}\text { Abutment } \\
\text { scour } \\
\text { depth } \\
\text { (feet) }\end{array}$ & $\begin{array}{l}\text { Pier } \\
\text { scour } \\
\text { depth } \\
\text { (feet) }\end{array}$ & $\begin{array}{l}\text { Depth of } \\
\text { total scour } \\
\text { (feet) }\end{array}$ & $\begin{array}{c}\text { Elevation of } \\
\text { scour }^{2} \\
\text { (feet) }\end{array}$ & $\begin{array}{c}\text { Remaining } \\
\text { footing/pile } \\
\text { depth } \\
\text { (feet) }\end{array}$ \\
\hline \multicolumn{12}{|c|}{100 -year discharge is 2,000 cubic-feet per second } \\
\hline Left abutment & 0.0 & 198.8 & 497.2 & 485.5 & 487.2 & 2.4 & 11.3 & -- & 13.7 & 473.5 & -12.0 \\
\hline Right abutment & 29.6 & 198.9 & 497.0 & 485.5 & 492.3 & 2.4 & 14.0 & -- & 16.4 & 475.9 & -9.6 \\
\hline
\end{tabular}

1.Measured along the face of the most constricting side of the bridge.

2.Arbitrary datum for this study.

Table 2. Remaining footing/pile depth at abutments for the 500-year discharge at structure LOWETH00020009 on Town Highway 2, crossing East Branch Missisquoi River, Lowell, Vermont.

[VTAOT, Vermont Agency of Transportation; --, no data]

\begin{tabular}{|c|c|c|c|c|c|c|c|c|c|c|c|}
\hline Description & Station $^{1}$ & $\begin{array}{c}\text { VTAOT } \\
\text { Bridge seat } \\
\text { elevation } \\
\text { (feet) }\end{array}$ & $\begin{array}{c}\text { Surveyed } \\
\text { minimum } \\
\text { low-chord } \\
\text { elevation }{ }^{2} \\
\text { (feet) }\end{array}$ & $\begin{array}{c}\text { Bottom of } \\
\text { footing } \\
\text { elevation } \\
\text { (feet) }\end{array}$ & $\begin{array}{c}\text { Channel } \\
\text { elevation at } \\
\text { abutment/ } \\
\text { pier }^{2} \\
\text { (feet) }\end{array}$ & $\begin{array}{l}\text { Contraction } \\
\text { scour depth } \\
\text { (feet) }\end{array}$ & $\begin{array}{l}\text { Abutment } \\
\text { scour } \\
\text { depth } \\
\text { (feet) }\end{array}$ & $\begin{array}{l}\text { Pier } \\
\text { scour } \\
\text { depth } \\
\text { (feet) }\end{array}$ & $\begin{array}{l}\text { Depth of } \\
\text { total scour } \\
\text { (feet) }\end{array}$ & $\begin{array}{c}\text { Elevation of } \\
\text { scour }^{2} \\
\text { (feet) }\end{array}$ & $\begin{array}{c}\text { Remaining } \\
\text { footing/pile } \\
\text { depth } \\
\text { (feet) }\end{array}$ \\
\hline \multicolumn{12}{|c|}{500 -year discharge is 2,770 cubic-feet per second } \\
\hline Left abutment & 0.0 & 198.8 & 497.2 & 485.5 & 487.2 & 3.2 & 5.3 & -- & 8.5 & 478.7 & -6.8 \\
\hline Right abutment & 29.6 & 198.9 & 497.0 & 485.5 & 492.3 & 3.2 & 15.6 & -- & 18.8 & 473.5 & -12.0 \\
\hline
\end{tabular}

1.Measured along the face of the most constricting side of the bridge.

2.Arbitrary datum for this study. 


\section{SELECTED REFERENCES}

Arcement, G.J., Jr., and Schneider, V.R., 1989, Guide for selecting Manning's roughness coefficients for natural channels and flood plains: U.S. Geological Survey Water-Supply Paper 2339, 38 p.

Barnes, H.H., Jr., 1967, Roughness characteristics of natural channels: U.S. Geological Survey Water-Supply Paper 1849,213 p.

Benson, M. A., 1962, Factors Influencing the Occurrence of Floods in a Humid Region of Diverse Terrain: U.S. Geological Survey WaterSupply Paper 1580-B, 64 p.

Brown, S.A. and Clyde, E.S., 1989, Design of riprap revetment: Federal Highway Administration Hydraulic Engineering Circular No. 11, Publication FHWA-IP-89-016, 156 p.

Federal Highway Administration, 1983, Runoff estimates for small watersheds and development of sound design: Federal Highway Administration Report FHWA-RD-77-158.

Federal Highway Administration, 1993, Stream Stability and Scour at Highway Bridges: Participant Workbook: Federal Highway Administration Report FHWA-HI-91-011.

Froehlich, D.C., 1989, Local scour at bridge abutments in Ports, M.A., ed., Hydraulic Engineering--Proceedings of the 1989 National Conference on Hydraulic Engineering: New York, American Society of Civil Engineers, p. 13-18.

Hayes, D.C.,1993, Site selection and collection of bridge-scour data in Delaware, Maryland, and Virginia: U.S. Geological Survey WaterResources Investigation Report 93-4017, 23 p.

Johnson, C.G. and Tasker, G.D.,1974, Progress report on flood magnitude and frequency of Vermont streams: U.S. Geological Survey OpenFile Report 74-130, 37 p.

Lagasse, P.F., Schall, J.D., Johnson, F., Richardson, E.V., Chang, F., 1995, Stream Stability at Highway Structures: Federal Highway Administration Hydraulic Engineering Circular No. 20, Publication FHWA-IP-90-014, 144 p.

Laursen, E.M., 1960, Scour at bridge crossings: Journal of the Hydraulics Division, American Society of Civil Engineers, v. 86, no. HY2, p. 39-53.

Potter, W. D., 1957a, Peak rates of runoff in the Adirondack, White Mountains, and Maine woods area, Bureau of Public Roads

Potter, W. D., 1957b, Peak rates of runoff in the New England Hill and Lowland area, Bureau of Public Roads

Richardson, E.V. and Davis, S.R., 1995, Evaluating scour at bridges: Federal Highway Administration Hydraulic Engineering Circular No. 18, Publication FHWA-IP-90-017, 204 p.

Richardson, E.V., Simons, D.B., and Julien, P.Y., 1990, Highways in the river environment: Federal Highway Administration Publication FHWA-HI-90-016.

Ritter, D.F., 1984, Process Geomorphology: W.C. Brown Co., Debuque, Iowa, 603 p.

Shearman, J.O., 1990, User's manual for WSPRO--a computer model for water surface profile computations: Federal Highway Administration Publication FHWA-IP-89-027, 187 p.

Shearman, J.O., Kirby, W.H., Schneider, V.R., and Flippo, H.N., 1986, Bridge waterways analysis model; research report: Federal Highway Administration Publication FHWA-RD-86-108, 112 p.

Talbot, A.N., 1887, The determination of water-way for bridges and culverts.

U.S. Geological Survey, 1986, Lowell, Vermont 7.5 Minute Series quadrangle map: U.S. Geological Survey Topographic Maps, Aerial photographs, 1981; Contour interval, 6 meters; Scale 1:24,000. 


\section{APPENDIX A: \\ WSPRO INPUT FILE}




\section{WSPRO INPUT FILE}

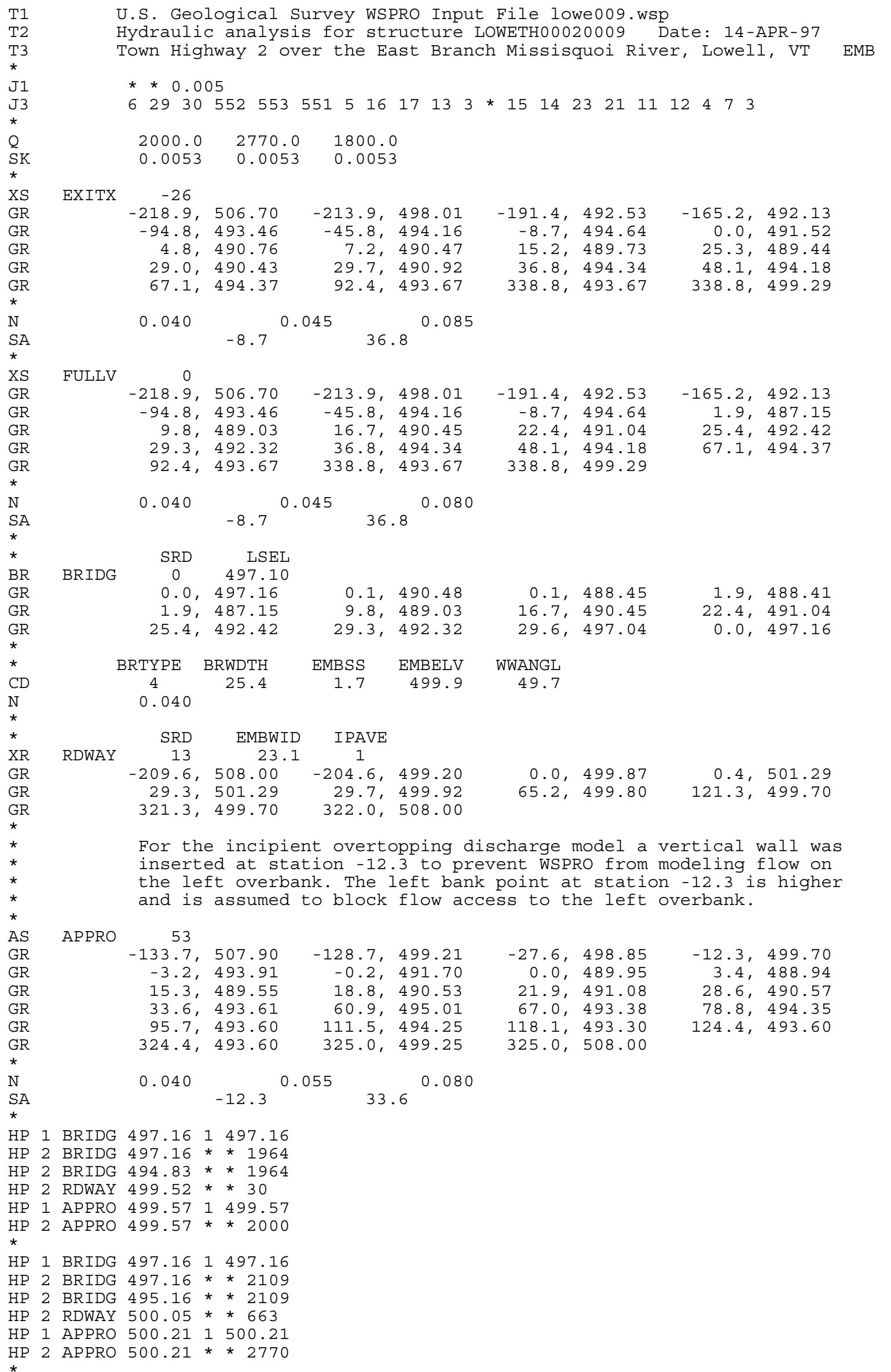


WSPRO INPUT FILE (continued)

HP 1 BRIDG 497.16 1497.16

HP 2 BRIDG 497.16 * * 1880

HP 2 BRIDG $494.76 *$ * 1880

HP 1 APPRO 499.231499 .23

HP 2 APPRO 499.23 * * 1880

EX

ER 


\section{APPENDIX B: \\ WSPRO OUTPUT FILE}


WSPRO OUTPUT FILE

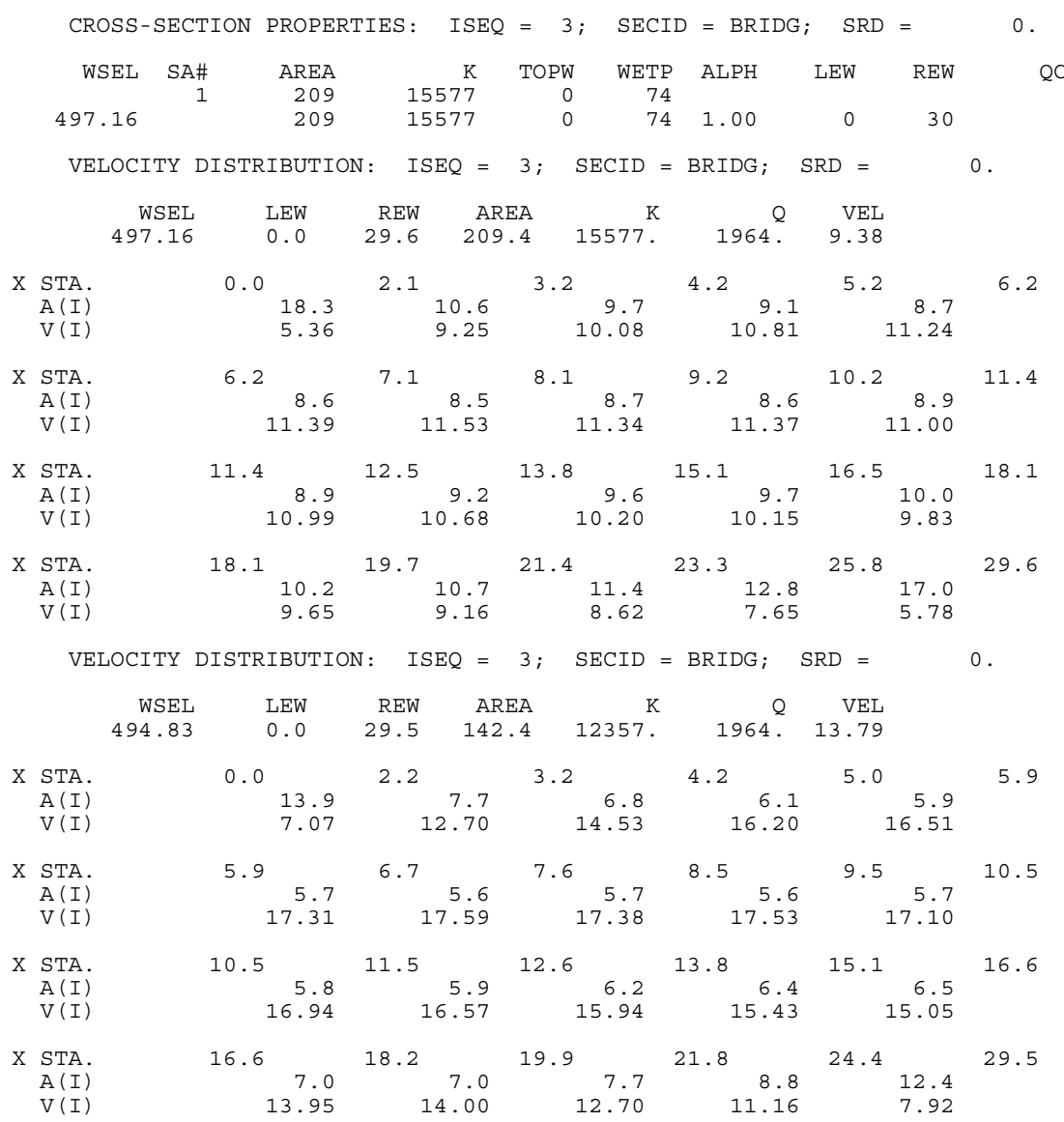

VELOCITY DISTRIBUTION: ISEQ $=4 ; \operatorname{SECID}=$ RDWAY $; \quad \operatorname{SRD}=13$.

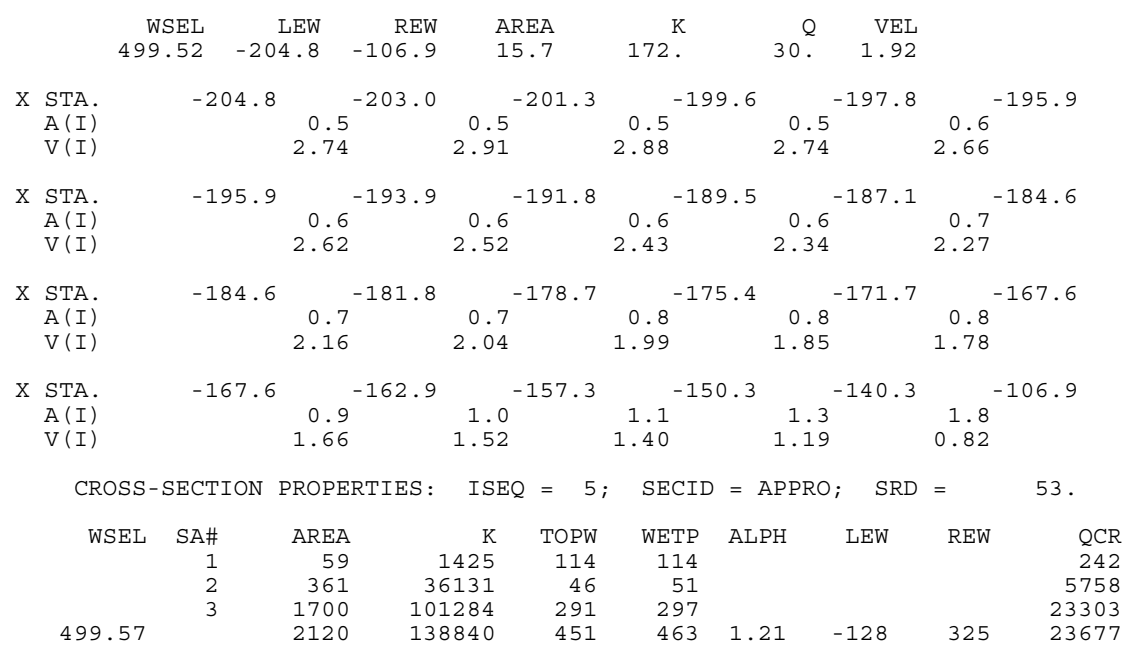

VELOCITY DISTRIBUTION: $\quad$ ISEQ $=5 ; \quad \operatorname{SECID~}=$ APPRO; $\quad \mathrm{SRD}=53$.

\begin{tabular}{|c|c|c|c|c|c|c|c|}
\hline & & $\begin{array}{r}\text { WSEL } \\
499.57\end{array}$ & $\begin{array}{r}\text { REW } \\
325.0\end{array}$ & $138840^{K}$. & $2000^{Q}$. & $\begin{array}{l}\text { VEL } \\
0.94\end{array}$ & \\
\hline & $\begin{array}{l}\text { STA. } \\
\text { A (I) } \\
\text { V (I) }\end{array}$ & $\begin{array}{r}-128.9 \\
139.1 \\
0.72\end{array}$ & $\begin{array}{r}3.2 \\
65.5 \\
1.53\end{array}$ & $\begin{array}{rr}9.5 & \\
& 60.5 \\
& 1.65\end{array}$ & $\begin{array}{rr}15.4 & \\
& 61.9 \\
& 1.61\end{array}$ & $\begin{array}{rr}22.2 & \\
& 61.6 \\
& 1.62\end{array}$ & 29.2 \\
\hline & $\begin{array}{l}\text { STA. } \\
\text { A (I) } \\
\text { V (I) }\end{array}$ & $\begin{array}{r}29.2 \\
101.6 \\
0.98\end{array}$ & $\begin{array}{r}46.0 \\
124.6 \\
0.80\end{array}$ & $\begin{array}{r}70.0 \\
119.3 \\
0.84\end{array}$ & $\begin{array}{r}91.5 \\
118.2 \\
0.85\end{array}$ & $\begin{array}{r}112.3 \\
113.4 \\
0.88\end{array}$ & 131.3 \\
\hline & $\begin{array}{l}\text { STA. } \\
\text { A (I) } \\
\text { V (I) }\end{array}$ & $\begin{array}{r}131.3 \\
112.9 \\
0.89\end{array}$ & $\begin{array}{r}150.2 \\
112.9 \\
0.89\end{array}$ & $\begin{array}{r}169.1 \\
114.3 \\
0.88\end{array}$ & $\begin{array}{r}188.3 \\
113.4 \\
0.88\end{array}$ & $\begin{array}{r}207.3 \\
112.8 \\
0.89\end{array}$ & 226.1 \\
\hline & $\begin{array}{l}\text { STA. } \\
\text { A (I) } \\
\text { V (I) }\end{array}$ & $\begin{array}{r}226.1 \\
114.3 \\
0.87\end{array}$ & $\begin{array}{r}245.3 \\
115.0 \\
0.87\end{array}$ & $\begin{array}{r}264.6 \\
113.7 \\
0.88\end{array}$ & $\begin{array}{r}283.6 \\
111.7 \\
0.90\end{array}$ & $\begin{array}{r}302.3 \\
133.8 \\
0.75\end{array}$ & 325.0 \\
\hline
\end{tabular}


WSPRO OUTPUT FILE (continued)

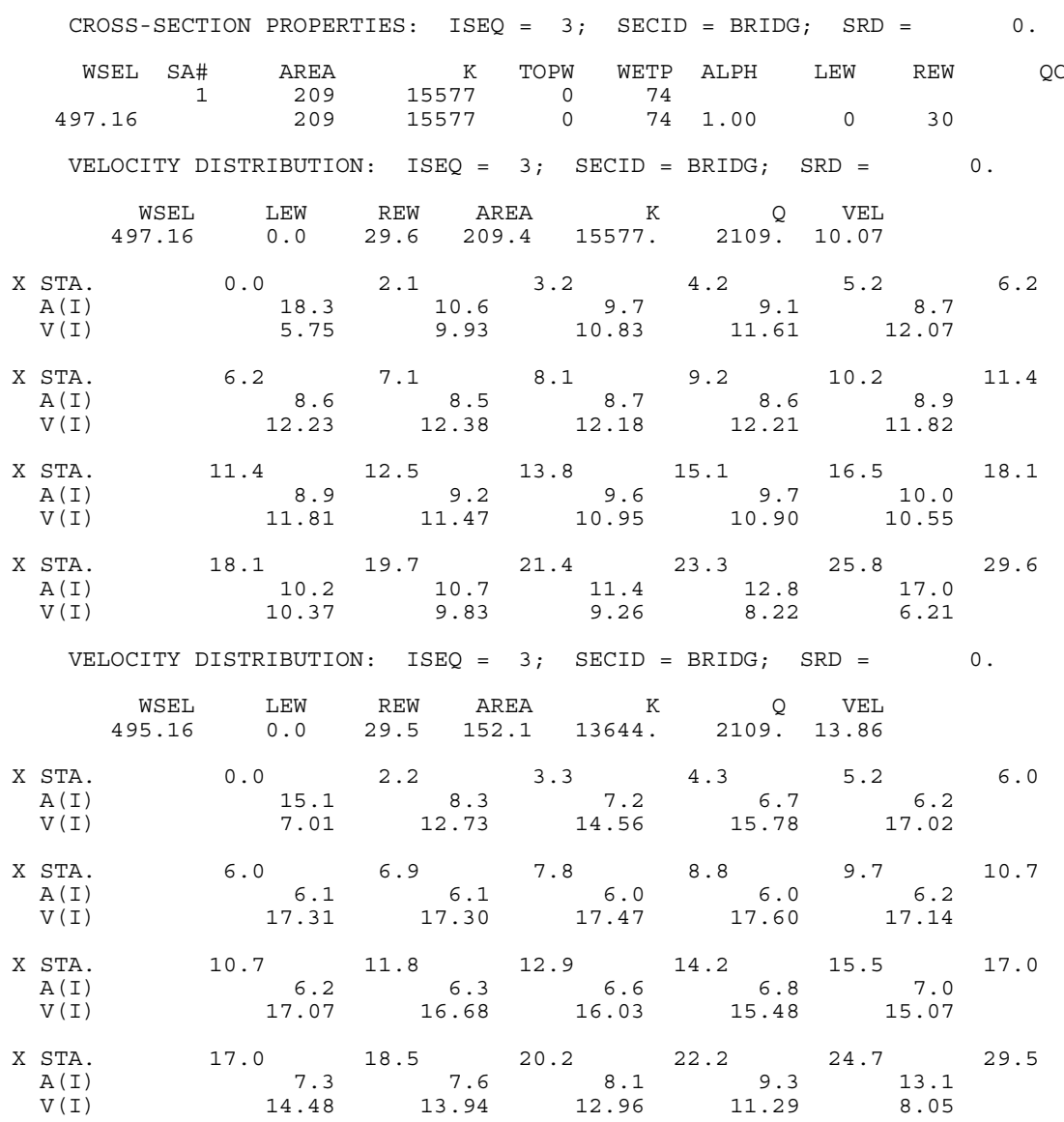

VELOCITY DISTRIBUTION: ISEQ $=4 ;$ SECID $=$ RDWAY $;$ SRD $=13$.

\begin{tabular}{|c|c|c|c|c|c|c|c|c|c|c|c|}
\hline \multicolumn{3}{|c|}{$\begin{array}{r}\text { WSEL } \\
500.05\end{array}$} & $\begin{array}{l}\text { LEW } \\
5.1\end{array}$ & $\begin{array}{r}\text { REW } \\
321.3\end{array}$ & & $\begin{array}{l}\mathrm{REA} \\
9.2\end{array}$ & $3369^{\mathrm{K}}$. & $\begin{array}{r}\text { Q } \\
663^{.} .\end{array}$ & $\begin{array}{r}\text { VEL } \\
3.33\end{array}$ & & \\
\hline$x$ & $\begin{array}{l}\text { STA. } \\
\text { A (I) } \\
\text { V(I) }\end{array}$ & -205.1 & $\begin{array}{r}5.5^{-} \\
6.05\end{array}$ & -198.3 & $6.36^{-}$ & -192.0 & $6^{5.14}{ }^{-18}$ & $\begin{array}{r}5.5 \\
6.03\end{array}$ & -178.1 & $\begin{array}{r}5.7^{-} \\
5.82^{-}\end{array}$ & -170.5 \\
\hline $\mathrm{x}$ & $\begin{array}{l}\text { STA. } \\
\text { A (I) } \\
\text { V(I) }\end{array}$ & -170.5 & $\begin{array}{r}5.8 \\
5.68\end{array}$ & -162.4 & ${ }^{6.1^{-}}$ & -153.7 & $\begin{array}{l}6.2^{-14} \\
5.36\end{array}$ & $\begin{array}{lr}.5 & \\
& 6.6 \\
& 4.99\end{array}$ & -134.0 & $\begin{array}{r}6.9^{-} \\
4.82^{-}\end{array}$ & -122.6 \\
\hline $\mathrm{x}$ & $\begin{array}{l}\text { STA. } \\
\text { A (I) } \\
\text { V(I) }\end{array}$ & -122.6 & $\begin{array}{l}7.2^{-} \\
4.62\end{array}$ & -109.8 & $\begin{array}{r}7.7 \\
4.30\end{array}$ & -94.8 & $3.5^{-7}$ & $\begin{array}{r}9.4 \\
3.51\end{array}$ & -52.3 & $\begin{array}{l}12.2 \\
2.72\end{array}$ & -8.6 \\
\hline $\mathrm{x}$ & $\begin{array}{l}\text { STA. } \\
\text { A (I) } \\
\text { V(I) }\end{array}$ & -8.6 & $\begin{array}{l}22.3 \\
1.49\end{array}$ & 112.6 & $\begin{array}{l}18.0 \\
1.85\end{array}$ & 164.2 & $\begin{array}{ll}18.6 \\
1.78\end{array}$ & $\begin{array}{ll}.3 & \\
& 18.2 \\
& 1.82\end{array}$ & 269.3 & $\begin{array}{l}18.2 \\
1.82\end{array}$ & 321.3 \\
\hline & CROSS - & SECTION & PROPER & RTIES: & ISEQ & $2=5 ;$ & SECID & $=A P P R O ;$ & SRD & $=$ & 53. \\
\hline & WSEL & $\begin{array}{r}\text { SA\# } \\
1 \\
2 \\
3\end{array}$ & $\begin{array}{r}\text { AREA } \\
134 \\
390 \\
1887 \\
2411\end{array}$ & $\begin{array}{l}12 \\
16\end{array}$ & $\begin{array}{r}\mathrm{K} \\
5439 \\
1030 \\
0298 \\
6766\end{array}$ & $\begin{array}{r}\text { TOPW } \\
117 \\
46 \\
291 \\
454\end{array}$ & $\begin{array}{r}\text { WETP } \\
118 \\
51 \\
298 \\
467\end{array}$ & ALPH & LEW & REW & $\begin{array}{r}\mathrm{QCR} \\
813 \\
6461 \\
27240 \\
28865\end{array}$ \\
\hline
\end{tabular}

VELOCITY DISTRIBUTION $: \quad$ ISEQ $=5 ; \quad$ SECID $=$ APPRO; $\quad$ SRD $=53$.

\begin{tabular}{|c|c|c|c|c|c|c|c|}
\hline & & $\begin{array}{rr}\text { WSEL } & \text { LEW } \\
500.21 & -129.3\end{array}$ & $\begin{array}{rr}\text { REW } & \text { AR } \\
325.0 & 2410\end{array}$ & $\begin{array}{lr}\text { EA } & \text { K } \\
.9 & 166766^{\prime} .\end{array}$ & $2770^{Q}$. & $\begin{array}{r}\text { VEL } \\
1.15\end{array}$ & \\
\hline S & $\begin{array}{l}\text { STA. } \\
\text { A (I) } \\
\text { V (I) }\end{array}$ & $\begin{array}{r}-129.3 \\
181.3 \\
0.76\end{array}$ & $\begin{aligned}-0.9 & \\
& 85.1 \\
& 1.63\end{aligned}$ & $\begin{array}{ll}7.1 & \\
& 69.9 \\
& 1.98\end{array}$ & $\begin{array}{r}13.5 \\
68.7 \\
2.02\end{array}$ & $\begin{array}{r}20.2 \\
71.1 \\
1.95\end{array}$ & 27.8 \\
\hline X & $\begin{array}{l}\text { STA. } \\
\text { A (I) } \\
\text { V (I) }\end{array}$ & $\begin{array}{r}27.8 \\
104.0 \\
1.33\end{array}$ & $\begin{array}{r}42.4 \\
139.1 \\
1.00\end{array}$ & $\begin{array}{r}66.6 \\
135.6 \\
1.02\end{array}$ & $\begin{array}{r}88.3 \\
128.1 \\
1.08\end{array}$ & $\begin{array}{r}108.4 \\
130.6 \\
1.06\end{array}$ & 128.5 \\
\hline$x$ & $\begin{array}{l}\text { STA. } \\
\text { A (I) } \\
\text { V (I) }\end{array}$ & $\begin{array}{r}128.5 \\
126.3 \\
1.10\end{array}$ & $\begin{array}{r}147.6 \\
126.3 \\
1.10\end{array}$ & $\begin{array}{r}166.7 \\
127.7 \\
1.08\end{array}$ & $\begin{array}{r}186.0 \\
126.7 \\
1.09\end{array}$ & $\begin{array}{r}205.2 \\
129.2 \\
1.07\end{array}$ & 224.7 \\
\hline & $\begin{array}{l}\text { STA. } \\
\text { A (I) } \\
\text { V (I) }\end{array}$ & $\begin{array}{r}224.7 \\
128.4 \\
1.08\end{array}$ & $\begin{array}{r}244.2 \\
125.1 \\
1.11\end{array}$ & $\begin{array}{r}263.1 \\
127.1 \\
1.09\end{array}$ & $\begin{array}{r}282.3 \\
129.9 \\
1.07\end{array}$ & $\begin{array}{r}302.0 \\
150.5 \\
0.92\end{array}$ & 325.0 \\
\hline
\end{tabular}


WSPRO OUTPUT FILE (continued)

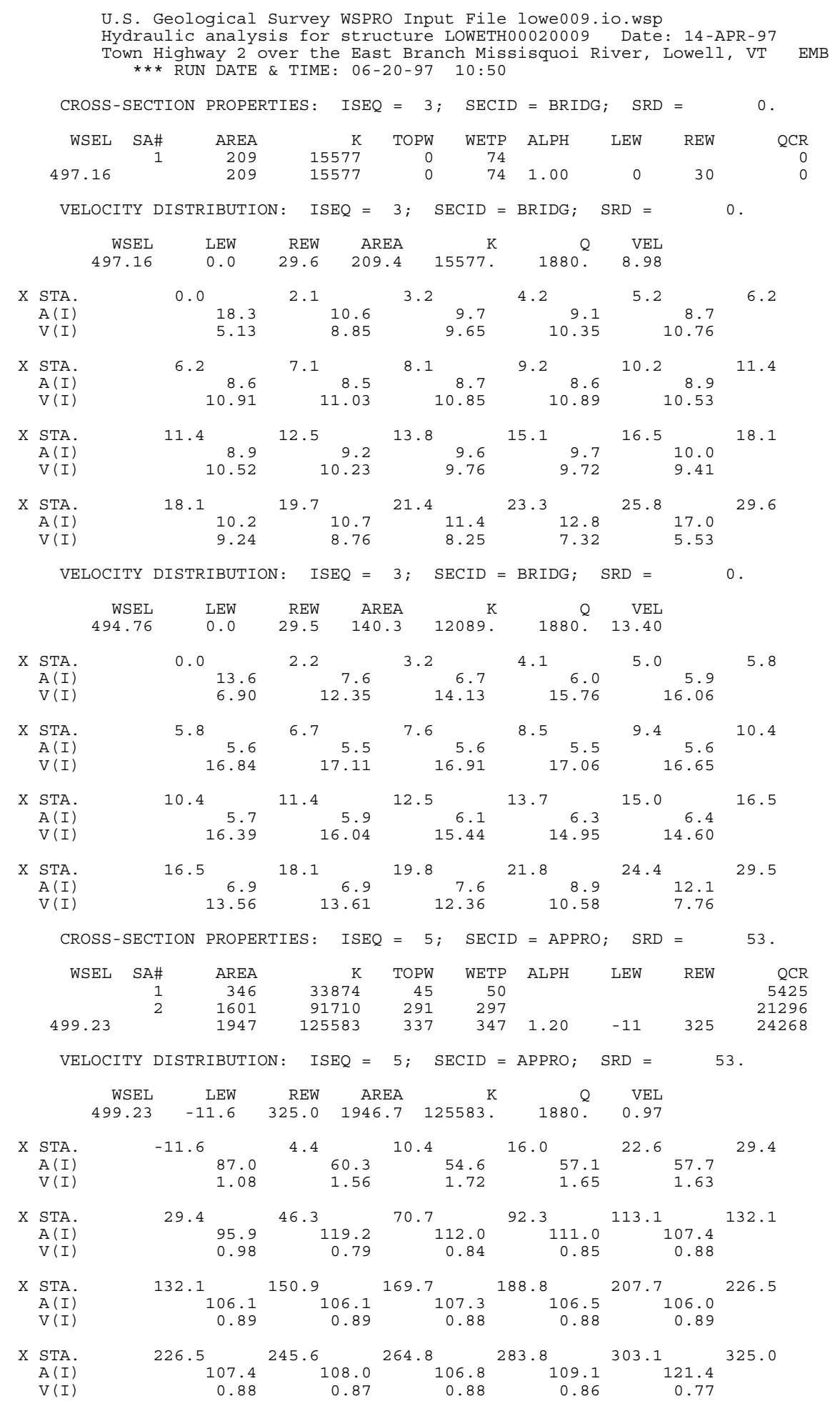


WSPRO OUTPUT FILE (continued)

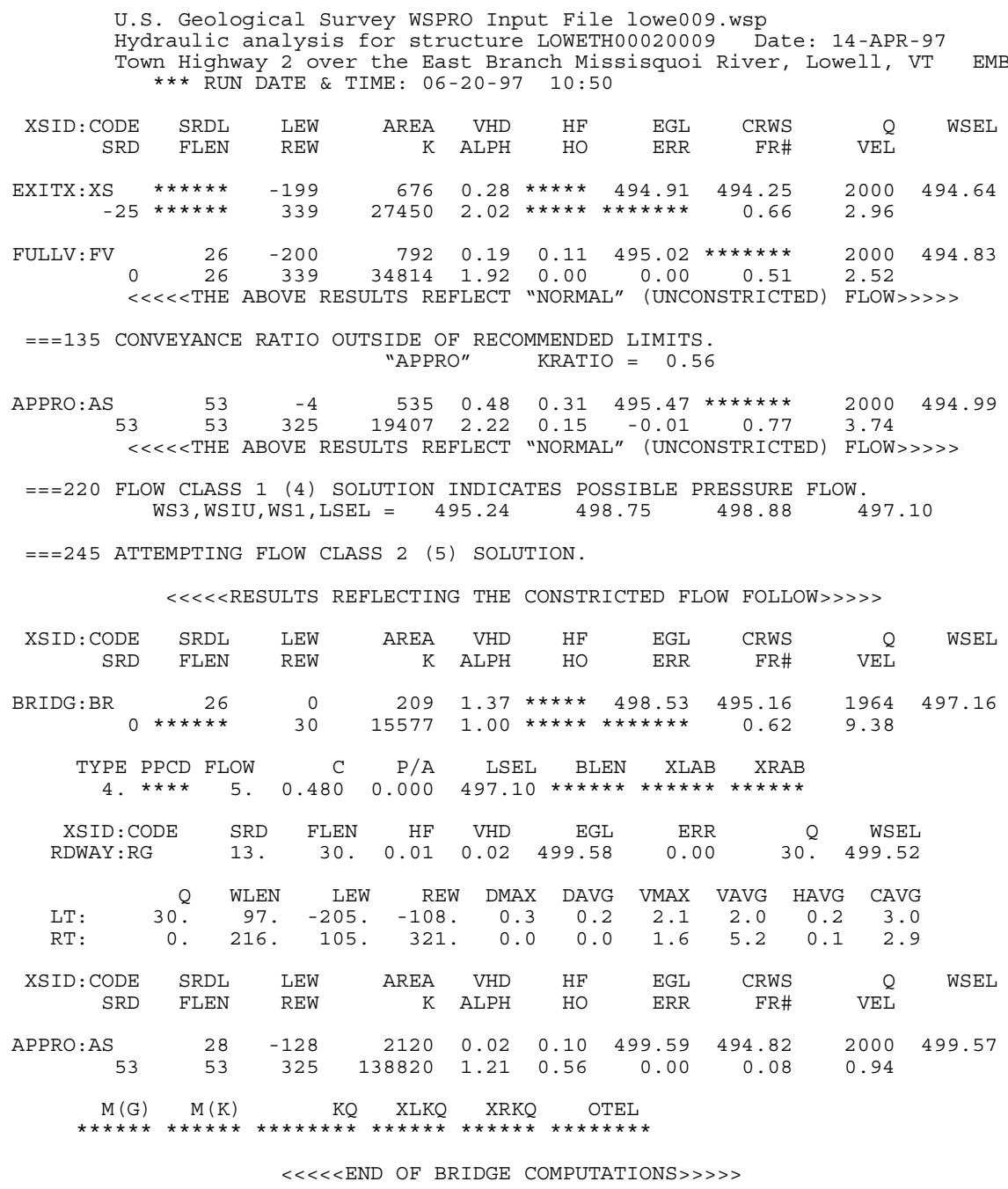

FIRST USER DEFINED TABLE.

\begin{tabular}{|c|c|c|c|c|c|c|c|c|}
\hline XSID : CODE & SRD & LEW & REW & $Q$ & $\mathrm{~K}$ & AREA & VEL & WSEL \\
\hline EXITX:XS & -26 . & -200 & 339. & 2000 . & 27450 . & 676. & 2.96 & 494.64 \\
\hline FULLV : FV & 0. & -201 & 339. & 2000 . & 34814 . & 792 . & 2.52 & 494.83 \\
\hline BRIDG : BR & 0 . & 0 . & 30. & 1964. & 15577. & 209. & 9.38 & 497.16 \\
\hline RDWAY : RG & $13 . *$ & 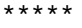 & 30. & 30. & 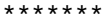 & 0 . & 1.00 & 499.52 \\
\hline APPRO: AS & 53. & -129. & 325. & 2000 . & 138820. & 2120 . & 0.94 & 499.57 \\
\hline CODE & XLKQ & XRKQ & & & & & & \\
\hline
\end{tabular}

SECOND USER DEFINED TABLE.

$\begin{array}{lcrrrrrrrr}\text { XSID : CODE } & \text { CRWS } & \text { FR\# } & \text { YMIN } & \text { YMAX } & \text { HF } & \text { HO } & \text { VHD } & \text { EGL } & \text { WSEL } \\ \text { EXITX :XS } & 494.25 & 0.66 & 489.44 & 506.70 * * * * * * * * * * * & 0.28 & 494.91 & 494.64 \\ \text { FULLV:FV } & * * * * * * * * & 0.51 & 487.15 & 506.70 & 0.11 & 0.00 & 0.19 & 495.02 & 494.83 \\ \text { BRIDG :BR } & 495.16 & 0.62 & 487.15 & 497.16 * * * * * * * * * * & 1.37 & 498.53 & 497.16 \\ \text { RDWAY: RG } & * * * * * * * * * * * * * * & 499.20 & 508.00 & 0.01 * * * * * * & 0.02 & 499.58 & 499.52 \\ \text { APPRO:AS } & 494.82 & 0.08 & 488.94 & 508.00 & 0.10 & 0.56 & 0.02 & 499.59 & 499.57\end{array}$


WSPRO OUTPUT FILE (continued)

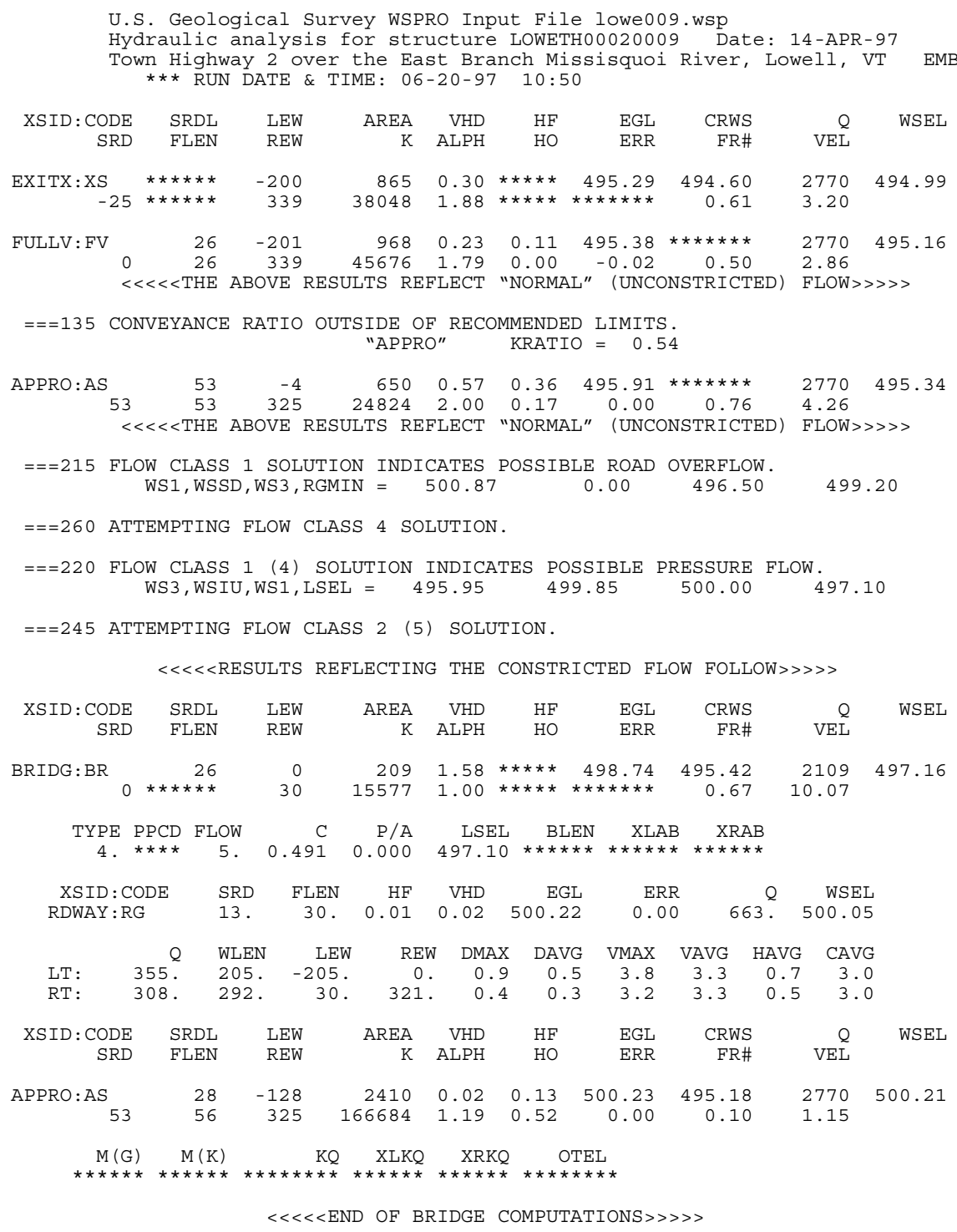

FIRST USER DEFINED TABLE.

\begin{tabular}{|c|c|c|c|c|c|c|c|c|}
\hline XSID: CODE & SRD & LEW & REW & Q & $\mathrm{K}$ & AREA & VEL & WSEL \\
\hline EXITX:XS & -26 & -201 & 339. & 2770 . & 38048 . & 865. & 3.20 & 494.99 \\
\hline FULLV : FV & 0. & -202 . & 339. & 2770 . & 45676 . & 968. & 2.86 & 495.16 \\
\hline BRIDG : BR & 0 . & 0 . & 30. & 2109. & 15577. & 209. & 10.07 & 497.16 \\
\hline RDWAY : RG & $13 . *$ & $* * * * * *$ & 355. & 663. & $\star \star \star \star \star \star \star \star * *$ & 0 . & 1.00 & 500.05 \\
\hline APPRO: AS & 53. & -129. & 325. & 2770 . & 166684. & 2410 . & 1.15 & 500.21 \\
\hline XSID : CODE & XLKQ & XRKQ & & & & & & \\
\hline
\end{tabular}

SECOND USER DEFINED TABLE.

$\begin{array}{lcrrrrrrrr}\text { XSID :CODE } & \text { CRWS } & \text { FR\# } & \text { YMIN } & \text { YMAX } & \text { HF } & \text { HO } & \text { VHD } & \text { EGL } & \text { WSEL } \\ \text { EXITX:XS } & 494.60 & 0.61 & 489.44 & 506.70 * * * * * * * * * * * & 0.30 & 495.29 & 494.99 \\ \text { FULLV:FV } & * * * * * * * * & 0.50 & 487.15 & 506.70 & 0.11 & 0.00 & 0.23 & 495.38 & 495.16 \\ \text { BRIDG :BR } & 495.42 & 0.67 & 487.15 & 497.16 * * * * * * * * * * & 1.58 & 498.74 & 497.16 \\ \text { RDWAY:RG } & * * * * * * * * * * * * * * & 499.20 & 508.00 & 0.01 * * * * * * & 0.02 & 500.22 & 500.05 \\ \text { APPRO :AS } & 495.18 & 0.10 & 488.94 & 508.00 & 0.13 & 0.52 & 0.02 & 500.23 & 500.21 \\ \text { ER } & & & & & & & & \end{array}$


WSPRO OUTPUT FILE (continued)

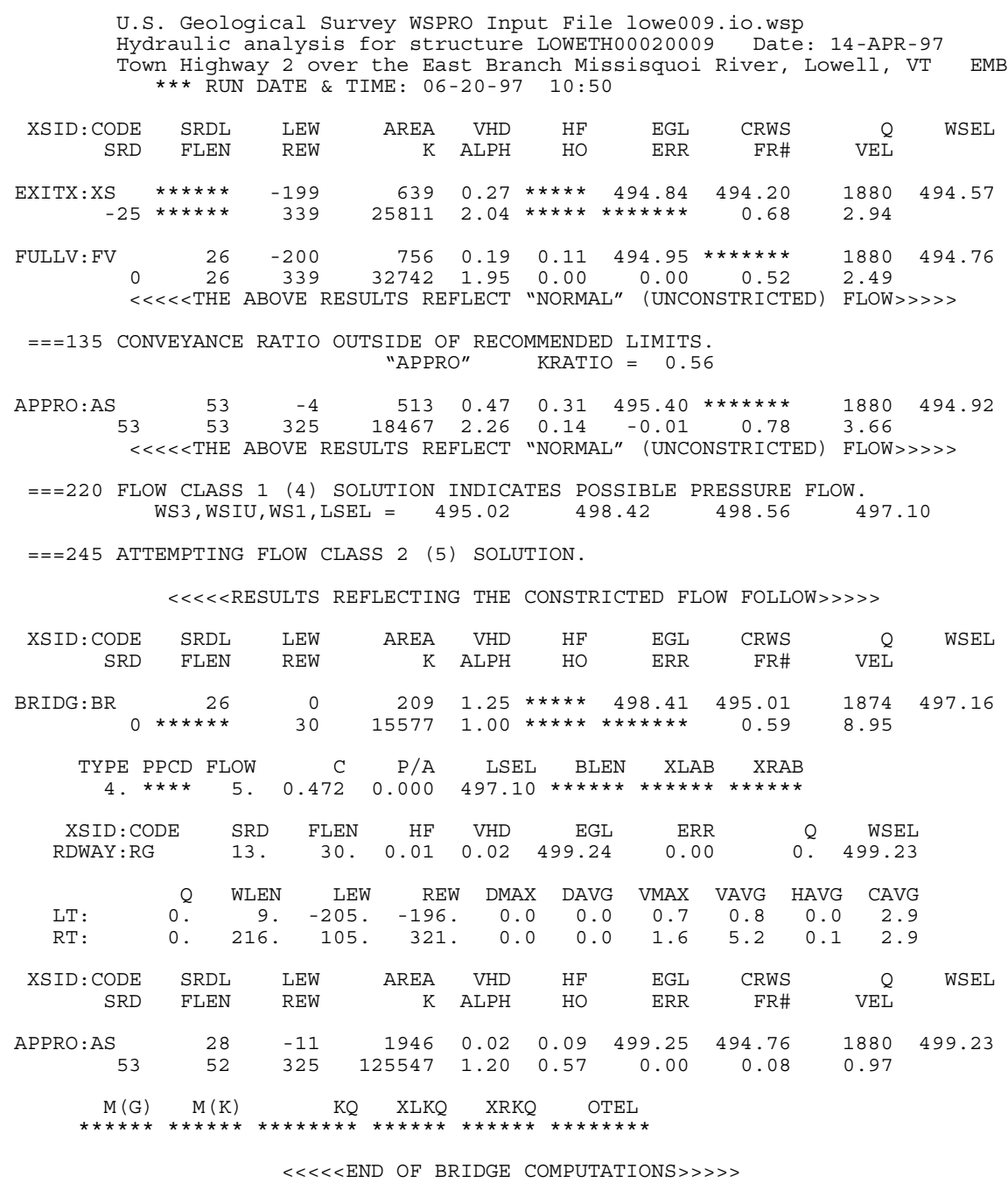

FIRST USER DEFINED TABLE.

$\begin{array}{lrrrrrrrr}\text { XSID }: \text { CODE } & \text { SRD } & \text { LEW } & \text { REW } & Q & \text { K } & \text { AREA } & \text { VEL } & \text { WSEL } \\ \text { EXITX }: \text { XS } & -26 . & -200 . & 339 . & 1880 . & 25811 . & 639 . & 2.94 & 494.57 \\ \text { FULLV }: \text { FV } & 0 . & -201 . & 339 . & 1880 . & 32742 . & 756 . & 2.49 & 494.76 \\ \text { BRIDG }: \text { BR } & 0 . & 0 . & 30 . & 1874 . & 15577 . & 209 . & 8.95 & 497.16 \\ \text { RDWAY }: \text { RG } & 13 . * * * * * * * & 0 . & 0 . * * * * * * * * & 0.0 & 0.0 & 1.00 & 499.23 \\ \text { APPRO }: \text { AS } & 53 . & -12 . & 325 . & 1880 . & 125547 . & 1946 . & 0.97 & 499.23\end{array}$

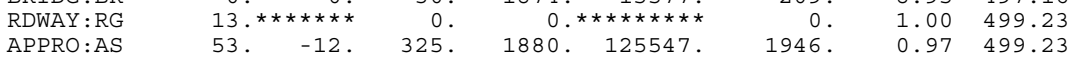

XSID: CODE XLKQ XRKQ KQ

APPRO: AS $* * * * * * * * * * * * * * * * * * * * * * *$

SECOND USER DEFINED TABLE.

\begin{tabular}{|c|c|c|c|c|c|c|c|c|c|}
\hline XSID : CODE & CRWS & FR\# & YMIN & YMAX & $\mathrm{HF}$ & $\mathrm{HO}$ & VHD & EGL & WSEL \\
\hline EXITX:XS & 494.20 & 0.68 & 489.44 & $506.70 *$ & $* \star \star \star * \star *$ & 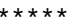 & 0.27 & 494.84 & 494.57 \\
\hline FULLV : FV & $\star * \star \star \star \star * \star * *$ & 0.52 & 487.15 & 506.70 & 0.11 & 0.00 & 0.19 & 494.95 & 494.76 \\
\hline BRIDG : BR & 495.01 & 0.59 & 487.15 & $497.16 *$ & $* \star \star * \star * \star$ & 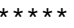 & 1.25 & 498.41 & 497.16 \\
\hline RDWAY : RG & $\star \star \star \star * \star * \star * \star * \star * \star * *$ & $\star * \star * *$ & 499.20 & 508.00 & $0.01 *$ & $\star \star \star \star * *$ & 0.02 & 499.24 & 499.23 \\
\hline APPRO:AS & 494.76 & 0.08 & 488.94 & 508.00 & 0.09 & 0.57 & 0.02 & 499.25 & 499.23 \\
\hline & & & & & & & & & \\
\hline
\end{tabular}




\section{APPENDIX C:}

\section{BED-MATERIAL PARTICLE-SIZE DISTRIBUTION}




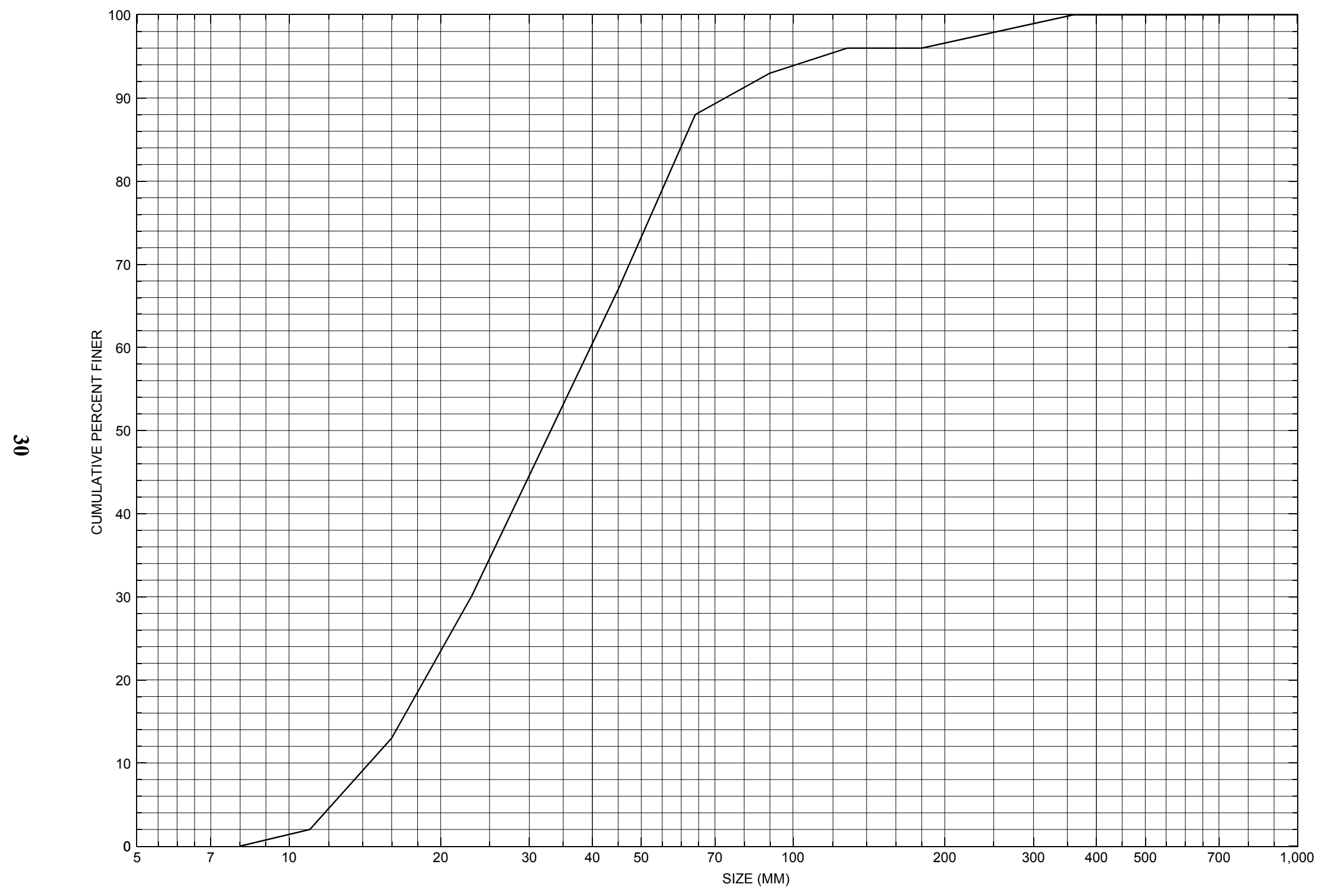

Appendix C. Bed material particle-size distribution for a pebble count in the channel approach of structure LOWETH00020009, in Lowell, Vermont. 


\section{APPENDIX D: \\ HISTORICAL DATA FORM}




\section{Structure Number LOWETH00020009}

\section{General Location Descriptive}

Data collected by (First Initial, Full last name) $\underline{\text { L }}$. MEDALIE

Date $(M M / D D / Y Y) \_\mathbf{0 3} / \underline{\mathbf{0 7}} / \underline{95}$

Highway District Number (I - 2; nn) $\mathbf{0 9}$

Town (FIPS place code; I - 4; nnnnn) $\mathbf{4 0 5 2 5}$

Waterway (I - 6) East Branch Missisquoi River

Route Number $\underline{\text { TH002 }}$

Topographic Map Lowell

Latitude (I - 16; nnnn.n) $\mathbf{4 4 4 7 8}$
County (FIPS county code; I - 3; nnn)

Mile marker (I - 11; nnn.nnn) $\mathbf{0 0 0 0 0 0}$

Road Name (I - 7): -

Vicinity (I - 9) 0.05 MI TO JCT W VT100

Hydrologic Unit Code: $\underline{\mathbf{0 2 0 1 0 0 0 7}}$

Longitude (i - 17; nnnnn.n) $\mathbf{7 2 2 7 0}$

\section{Select Federal Inventory Codes}

FHWA Structure Number (I - 8) 10101300091013

Maintenance responsibility $(I-21 ; n n) \quad \mathbf{0 3} \quad$ Maximum span length $(I-48 ; n n n n) \underline{\mathbf{0 0 3 0}}$

Year built (I - 27; YYYY) 1952

Structure length (I - 49; nnnnnn) $\underline{\mathbf{0 0 0 0 3 3}}$

Average daily traffic, ADT (I - 29; nnnnnn) 000250

Deck Width (I - 52; nn.n) 231

Year of ADT (I - 30; YY) $\mathbf{9 4}$

Channel \& Protection $(I-61 ; n) \underline{\mathbf{5}}$

Opening skew to Roadway $(I-34 ; n n) \quad \mathbf{0 0}$

Waterway adequacy $(I-71 ; n)$

Operational status $(I-41 ; X) \quad \mathbf{A}$

Underwater Inspection Frequency $(I-92 B ; X Y Y) \_\mathbf{N}$

Structure type (I - 43; nnn) 104

Year Reconstructed (I - 106) $\mathbf{0 0 0 0}$

Approach span structure type (I - 44; nnn) $\mathbf{0 0 0}$

Clear span $(n n n . n f t) \quad \mathbf{3 0 . 0}$

Number of spans (I - 45; nnn) $\mathbf{0 0 1}$

Vertical clearance from streambed (nnn.n ft) $\underline{\mathbf{7 . 5}}$

Number of approach spans (I- 46; nnnn) $\underline{\mathbf{0 0 0 0}}$ Waterway of full opening $\left(n n n . n \mathrm{ft}^{2}\right) \underline{\mathbf{2 2 5 . 0}}$

Comments:

The structural inspection report of 6/1/93 indicates the structure is a concrete T-beam type bridge. The concrete along the top of each upstream wingwall reportedly has spalled. The front faces of the upstream wingwalls have numerous cracks with leakage noted. The entire length of the left abutment footing is exposed. The streambed is between 1 and 1.5 feet below the top of the footing with no apparent undermining. The waterway makes a sharp turn into the structure. The resulting impact of the flow is mainly on the left abutment. There is a 3 foot high silt and sand point bar that extends along the right abutment with some vegetation growing on it. The streambed consists of sand and gravel, (Continued, page 34) 


\section{Bridge Hydrologic Data}

Is there hydrologic data available? $\underline{\mathbf{N}}$ if No, type ctrl- $n$ VTAOT Drainage area $\left(\mathrm{mi}^{2}\right)$ : -

Terrain character:

Stream character \& type: -

Streambed material: Sand and gravel, some random stones

Discharge Data (cfs): $\quad Q_{2.33}-$

$$
\mathrm{Q}_{50}-
$$

$\mathrm{Q}_{25}$

$\mathrm{Q}_{500}$

Record flood date $(M M / D D / Y Y):-$

Water surface elevation $(f t):-$

Estimated Discharge (cfs): Velocity at $\mathrm{Q}-$ $(\mathrm{ft} / \mathrm{s}):$

Ice conditions (Heavy, Moderate, Light) : -

Debris (Heavy, Moderate, Light):

The stage increases to maximum highwater elevation (Rapidly, Not rapidly):

The stream response is (Flashy, Not flashy):

Describe any significant site conditions upstream or downstream that may influence the stream's stage: -

Watershed storage area (in percent):

The watershed storage area is: - _ (1-mainly at the headwaters; 2- uniformly distributed; 3-immediatly upstream oi the site)

Water Surface Elevation Estimates for Existing Structure:

\begin{tabular}{|l|l|l|l|l|l|}
\hline Peak discharge frequency & $Q_{2.33}$ & $Q_{10}$ & $Q_{25}$ & $Q_{50}$ & $Q_{100}$ \\
Water surface elevation (ft)) & - & - & - & - & - \\
Velocity (ft/sec) & - & - & - & - & - \\
\hline
\end{tabular}

Long term stream bed changes: -

Is the roadway overtopped below the $Q_{100}$ ? (Yes, No, Unknown):

Frequency: -

Relief Elevation (ft):

Discharge over roadway at $Q_{100}\left(f^{3} / \mathrm{sec}\right)$ :

Are there other structures nearby? (Yes, No, Unknown): If No or Unknown, type ctrl-n os Upstream distance (miles): Town: Year Built:

Highway No. : Structure No. : -

Clear span (ft): Clear Height (ft): Full Waterway $\left(f t^{2}\right)$ : 
Downstream distance (miles): Town: Year Built:

Highway No. : Structure No. : Structure Type:

Clear span (ft): Clear Height $(f t)$ : Full Waterway $\left(f^{2}\right)$ :

Comments:

with some small cobbles. Some minor bank erosion is noted at the up- and downstream ends of the left abutment. Not much stone fill protection is present. The bridge opening is constricted somewhat by the point bar under the bridge.

\section{USGS Watershed Data}

Watershed Hydrographic Data

Drainage area $(D A) \underline{\mathbf{1 3 . 5 0}} \mathrm{mi}^{2}$ Lake and pond area $\mathbf{0 . 0 1}$ $\mathrm{mi}^{2}$

Watershed storage (ST)

Bridge site elevation 908 0.1 $\%$

Main channel length $\mathbf{5 . 7 6}$ $\mathrm{ft}$ Headwater elevation 2618 $\mathrm{ft}$ $10 \%$ channel length elevation $\mathbf{9 2 5}$ $\mathrm{ft} \quad 85 \%$ channel length elevation $\mathrm{ft}$

Main channel slope $(S)$

(S) 118.45 $\mathrm{ft} / \mathrm{mi}$

Watershed Precipitation Data

Average site precipitation in Average headwater precipitation in

Maximum 2yr-24hr precipitation event $(124,2) \underline{2.23}$ in

Average seasonal snowfall $(S n) \_\mathbf{8 . 3 3} \mathrm{ft}$ 


\section{Bridge Plan Data}

Are plans available? $\mathbf{Y}$ If no, type ctrl-n pl Date issued for construction (MM/YYYY): _- / 1953 Project Number SA 381952

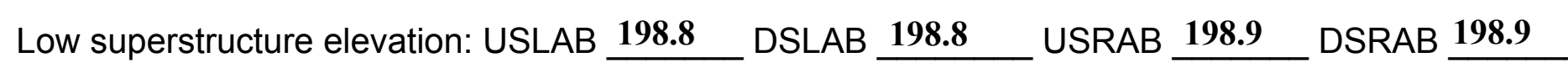
Benchmark location description:

BM \#1 - Spike in trunk of a 24 inch elm tree, located about 180 feet right bankward of bridge on left bank of a side brook, elevation 200.00 .

Reference Point (MSL, Arbitrary, Other): Arbitrary $\quad$ Datum (NAD27, NAD83, Other): Arbitrary Foundation Type: 1

If 1 : Footing Thickness $\mathbf{2 . 0} \quad$ Footing bottom elevation: $\underline{\mathbf{1 6 5 . 0}}$

If 2: Pile Type: ___ (1-Wood; 2-Steel or metal; 3-Concrete) Approximate pile driven length: -

If 3: Footing bottom elevation: -

Is boring information available? $\mathbf{N}$ If no, type ctrl-n bi Number of borings taken: -

Foundation Material Type: ____ (1-regolith, 2-bedrock, 3-unknown)

Briefly describe material at foundation bottom elevation or around piles:

$-$

Comments:

The streambed material was graded under the bridge such that the bed elevation was between 1 and 3 feet above the top of both abutment footings. The streambed is higher over the right abutment footing than the left. 


\section{Cross-sectional Data}

Is cross-sectional data available? $\underline{\mathbf{Y}}$

If no, type ctrl-n xs

Source (FEMA, VTAOT, Other)? VTAOT

Upstream bridge cross section at stationing $0+80$, nearest the upstream bridge face. The Comments: channel baseline runs along the left bank 1 foot from the streamward left abutment face.

\begin{tabular}{|l|l|l|l|l|l|l|l|l|l|l|l|}
\hline Station & $\mathbf{1 . 0}$ & $\mathbf{1 . 5}$ & $\mathbf{3 . 0}$ & $\mathbf{7 . 0}$ & $\mathbf{1 0 . 5}$ & $\mathbf{2 9 . 0}$ & $\mathbf{3 0 . 6}$ & $\mathbf{3 1 . 0}$ & & & \\
\hline Feature & LCL & BLB & $\begin{array}{l}\text { footing } \\
\text { edge }\end{array}$ & & & $\begin{array}{l}\text { footing } \\
\text { edge }\end{array}$ & BRB & LCR & & & \\
\hline $\begin{array}{l}\text { Low cord } \\
\text { elevation }\end{array}$ & 199.5 & & $\mathbf{t 1 8 9 . 5}$ & & & $\mathbf{t 1 8 9 . 5}$ & & 199.5 & & & \\
\hline $\begin{array}{l}\text { Bed } \\
\text { elevation }\end{array}$ & & 191.5 & $\mathbf{b 1 8 7 . 5}$ & $\mathbf{1 9 0 . 5}$ & $\mathbf{1 9 1 . 0}$ & $\mathbf{b 1 8 7 . 5}$ & $\mathbf{1 9 1 . 0}$ & & & & \\
\hline $\begin{array}{l}\text { Low cord to } \\
\text { bed length }\end{array}$ & & & & & & & & & & & \\
\hline Station & & & & & & & & & & & \\
\hline Feature & & & & & & & & & & & \\
\hline $\begin{array}{l}\text { Low cord } \\
\text { elevation }\end{array}$ & & & & & & & & & & & \\
\hline $\begin{array}{l}\text { Bed } \\
\text { elevation }\end{array}$ & & & & & & & & & & & \\
\hline $\begin{array}{l}\text { Low cord to } \\
\text { bed length }\end{array}$ & & & & & & & & & & & \\
\hline
\end{tabular}

Source (FEMA, VTAOT, Other)? VTAOT

Comments: Downstream bridge cross section at stationing $0+70$, most representable for the downstream bridge face.

\begin{tabular}{|l|l|l|l|l|l|l|l|l|l|l|l|}
\hline Station & $\mathbf{1 . 0}$ & $\mathbf{1 . 5}$ & $\mathbf{3 . 0}$ & $\mathbf{1 0 . 5}$ & $\mathbf{2 9 . 0}$ & $\mathbf{3 0 . 6}$ & $\mathbf{3 1 . 0}$ & & & & \\
\hline Feature & LCL & BLB & $\begin{array}{l}\text { footing } \\
\text { edge }\end{array}$ & & $\begin{array}{l}\text { footing } \\
\text { edge }\end{array}$ & BRB & LCR & & & & \\
\hline $\begin{array}{l}\text { Low cord } \\
\text { elevation }\end{array}$ & 199.5 & & $\mathbf{t 1 8 9 . 5}$ & & $\mathbf{t 1 8 9 . 5}$ & & $\mathbf{1 9 9 . 5}$ & & & & \\
\hline $\begin{array}{l}\text { Bed } \\
\text { elevation }\end{array}$ & & $\mathbf{1 9 0 . 5}$ & $\mathbf{b 1 8 7 . 5}$ & $\mathbf{1 9 0 . 5}$ & $\mathbf{b 1 8 7 . 5}$ & $\mathbf{1 9 0 . 5}$ & & & & & \\
\hline $\begin{array}{l}\text { Low cord to } \\
\text { bed length }\end{array}$ & & & & & & & & & & & \\
\hline Station & & & & & & & & & & & \\
\hline Feature & & & & & & & & & & & \\
\hline $\begin{array}{l}\text { Low cord } \\
\text { elevation }\end{array}$ & & & & & & & & & & & \\
\hline $\begin{array}{l}\text { Bed } \\
\text { elevation }\end{array}$ & & & & & & & & & & & \\
\hline $\begin{array}{l}\text { Low cord to } \\
\text { bed length }\end{array}$ & & & & & & & & & & & \\
\hline
\end{tabular}




\section{APPENDIX E: \\ LEVEL I DATA FORM}


U. S. Geological Survey

Bridge Field Data Collection and Processing Form

Qa/Qc Check by: RB Date: $4 / 8 / 96$

\section{Structure Number}

LOWETH00020009

Computerized by: $\underline{\mathbf{R B}}$ Date: $4 / 12 / 96$

Reviewd by:

EMB Date: $\underline{5 / 12 / 97}$

\section{A. General Location Descriptive}

1. Data collected by (First Initial, Full last name) $\underline{\text { E. BOEHMLER }} \underline{\text { BOH Date }(M M / D D / Y Y)} \underline{\mathbf{6}} / \underline{13} / \underline{1995}$

2. Highway District Number $\mathbf{0 9}$

County ORLEANS (019)

Waterway (I - 6) East Branch Missisquoi River

Route Number TH 2

3. Descriptive comments:

The bridge is located about 0.05 miles west of the intersection of TH 2 with VT Route 100.
Mile marker 000

Town LOWELL (40525)

Road Name -

Hydrologic Unit Code: $\mathbf{0 2 0 1 0 0 0 7}$

\section{B. Bridge Deck Observations}
4. Surface cover... LBUS 6
RBUS 5
LBDS 4
RBDS 5
Overall 5

(2b us, ds,lb,rb: 1- Urban; 2- Suburban; 3- Row crops; 4- Pasture; 5- Shrub- and brushland; 6- Forest; 7- Wetland)
5. Ambient water surface... US $\underline{2}$
UB 1
DS $\underline{2}$
(1- pool; 2- riffle)

6. Bridge structure type 1 (1- single span; 2- multiple span; 3- single arch; 4- multiple arch; 5-cylindrical culvert; 6- box culvert; or 7- other)
7. Bridge length $\mathbf{3 3}$
(feet)
Span length $\underline{\mathbf{3 0}}$
(feet)
Bridge width 23.1 (feet)

\section{Road approach to bridge:}
8. LB $\underline{0}$ RB $\underline{0}$
( 0 even, 1- lower, 2- higher)
9. LB 1
RB 1
(1- Paved, 2- Not paved)

10. Embankment slope (run / rise in feet / foot)

$$
\text { US left }
$$

1.5:1

US right

2.0:1

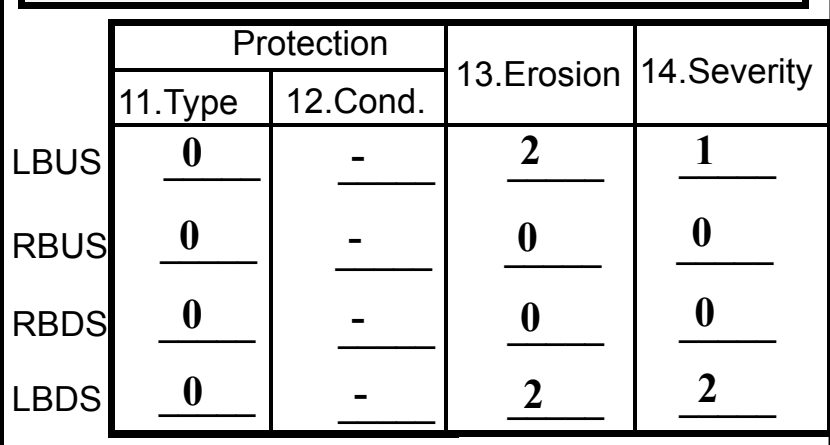

Bank protection types: 0- none; 1- $<12$ inches;

2- < 36 inches; 3- < 48 inches;

4- < 60 inches; 5- wall / artificial levee

Bank protection conditions: 1- good; 2- slumped;

3- eroded; 4- failed

Erosion: 0 - none; 1- channel erosion; 2 -

road wash; 3- both; 4- other

Erosion Severity: 0 - none; 1- slight; 2- moderate; 3- severe

\section{Channel approach to bridge (BF):}

15. Angle of approach: $\underline{\mathbf{3 0}}$

16. Bridge skew: $\mathbf{1 0}$

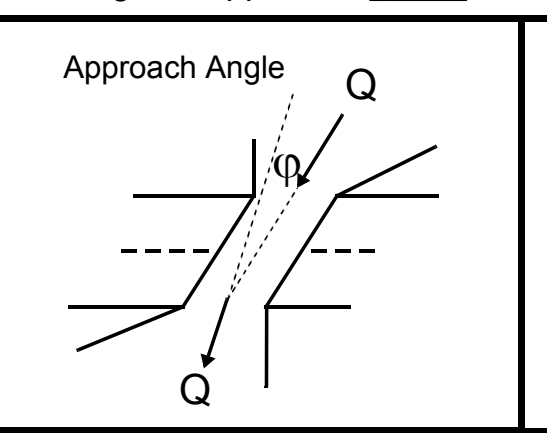

17. Channel impact zone 1 :

Where? LB $(L B, R B)$

Range? 2 feet $\underline{\text { US }}$

Channel impact zone 2:

Where? RB (LB, RB) Bridge Skew Angle

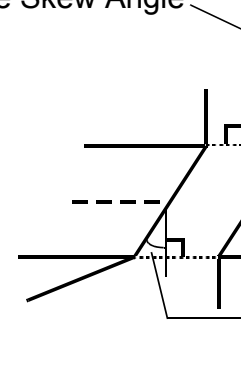

\section{Exist? $\underline{\mathbf{Y}}(\mathrm{Y}$ or $N)$}

Severity 2

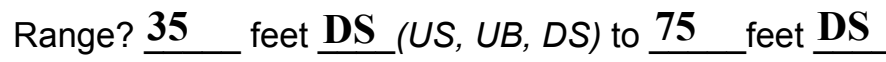

Impact Severity: 0- none to very slight; 1-Slight; 2- Moderate; 3- Severe 
18. Bridge Type: 4

1a- Vertical abutments with wingwalls

1 b- Vertical abutments without wingwalls

2- Vertical abutments and wingwalls, sloping embankment

Wingwalls perpendicular to abut. face

3- Spill through abutments

4- Sloping embankment, vertical wingwalls and abutments
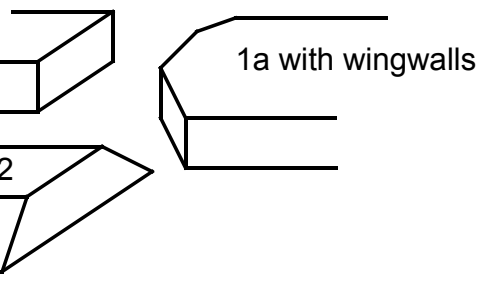

Wingwall angle less than $90^{\circ}$.

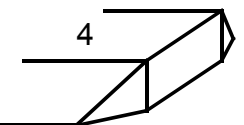

19. Bridge Deck Comments (surface cover variations, measured bridge and span lengths, bridge type variations, approach overflow width, etc.)

The bridge dimensions measured were the same as the VTOAT values shown on the previous page.

The US left bank surface cover is mainly trees on the bank and a gravel parking lot on the overbank. The US right overbank is a low-lying area with mostly shrubs and a few trees. The right overbank DS is occupied mostly by shrubs with a few trees. The downstream left overbank surface cover consists of pasture with a few trees and shrubs on the immediate bank.

\section{Upstream Channel Assessment}

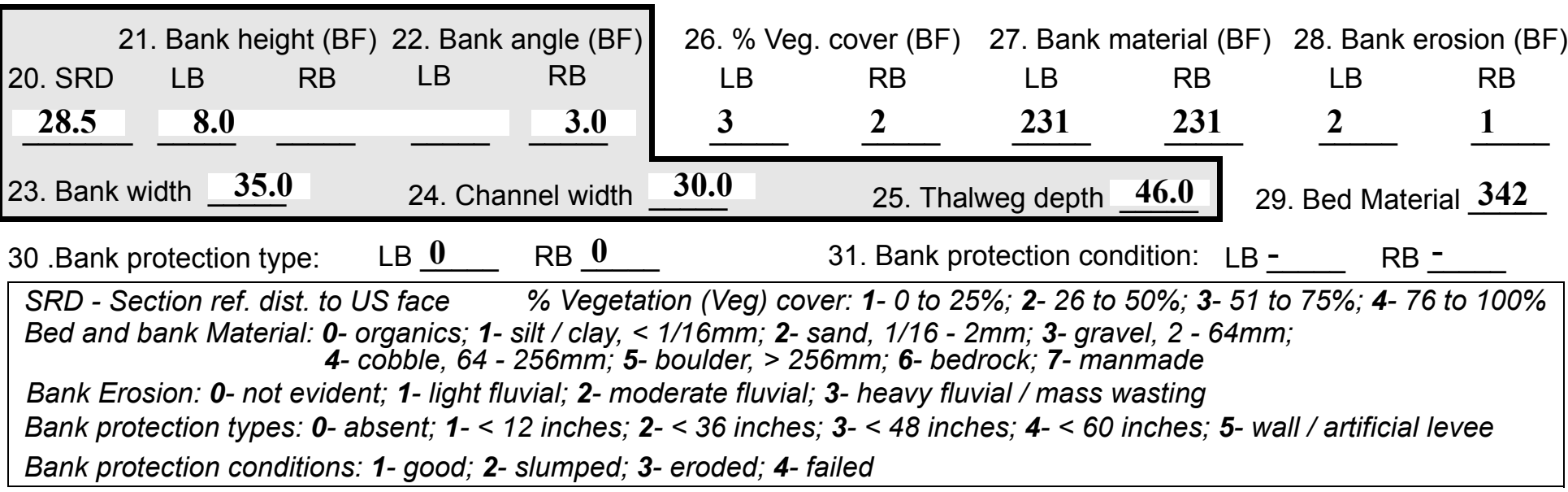

32. Comments (bank material variation, minor inflows, protection extent, etc.):

The bed material is mainly medium to coarse gravel with some medium to coarse sand and a few cobbles. The bank material is mainly medium sand with some fine gravel.

There is a zone of channel transition where the US end of the point bar is eroding.

A large debris jam, composed of whole trees and lots of branches, spans the entire channel about 140 feet US. One fallen tree forms the backbone of the debris jam. It fell from the right bank to the left bank where the top of the tree is braced by a live tree and prevents it from dislodging. Other trees and branches have accumulated on the braced tree during recent flood events. The debris jam blocks the entire channel such that the flow deflected under the jam has eroded the stream bed about 2 feet below the ambient depth of the channel. 
38. Point or side bar comments (Circle Point or Side; Note additional bars, material variation, status, etc.):

The point bar material at the upstream end is coarse gravel and cobbles. The material size grades finer to fine gravel and sand from 30 feet upstream to the upstream bridge face and medium to fine sand and silt along the right abutment.

\section{Is a cut-bank present? $\underline{\mathbf{Y}}$ (Y or if $N$ type ctrl-n cb) 40. Where? $\underline{\mathbf{L B}}$ (LB or RB)}

41. Mid-bank distance: $\underline{45}$ 42. Cut bank extent: 115 feet $\underline{\mathbf{U S}}$ (US, UB) to $\underline{\mathbf{2 0}}$ feet $\underline{\text { US }}$ (US, UB, DS)

43. Bank damage: 2 (1- eroded and/or creep; 2- slip failure; 3- block failure)

44. Cut bank comments (eg. additional cut banks, protection condition, etc.):

Most of the trees and shrubs on the bank are leaning at an angle greater than $\mathbf{4 5}$ degrees from vertical toward the channel. The cut bank is evident particularly in the range of 72 feet US to 20 feet US.

\section{Is channel scour present? $\mathbf{N}$ ( $Y$ or if $N$ type ctrl-n cs) 46. Mid-scour distance: -}
47. Scour dimensions: Length -
Width -
Depth : -
Position - $\%$ LB to - $\%$ RB

48. Scour comments (eg. additional scour areas, local scouring process, etc.):

\section{NO CHANNEL SCOUR}

Some channel scour is evident under the debris jam about 140 feet upstream.

49. Are there major confluences? $\mathbf{N}$

51. Confluence 1: Distance -

Confluence 2: Distance -

52. Enters on -

54. Confluence comments (eg. confluence name):

NO MAJOR CONFLUENCES ( $Y$ or if $N$ type ctrl-n $m c)$ (LB or $R B)$

50. How many? -

53. Type(1- perennial; 2- ephemeral)

Enters on (LB or $R B)$ (1- perennial; 2- ephemeral)

\section{Under Bridge Channel Assessment}

55. Channel restraint (BF)? LB 2

56. Height (BF)
LB RB
$\mathbf{2 8 . 5}-$
58. Bank width (BF) -
59. Channel width (Amb) 57 Angle (BF) LB RB 1.5 (1- natural bank; 2- abutment; 3- artificial levee)

Bed and bank Material: 0- organics; 1- silt / clay, < 1/16mm; 2- sand, 1/16 - 2mm; 3- gravel, 2 - 64mm; 4- cobble, 64 - 256mm; 5- boulder, > 256mm; 6- bedrock; 7- manmade

Bank Erosion: 0- not evident; 1- light fluvial; 2- moderate fluvial; 3- heavy fluvial / mass wasting

64. Comments (bank material variation, minor inflows, protection extent, etc.):

324

The bed material is medium to coarse gravel and sand with some cobbles. The bed material grades coarser from right to left under the bridge. The point bar, along the right abutment, is silt and fine sand. 
65. Debris and Ice Is there debris accumulation?

67. Debris Potential 1 (1- Low; 2- Moderate; 3- High)

69. Is there evidence of ice build-up? $\underline{2}(Y$ or $N)$

70. Debris and Ice Comments:

2

The capture efficiency is moderate because the left abutment protrudes and there is a point bar on the right abutment. Also the water is pooled under the bridge and the velocity is low. The debris potential is high because there are many trees on unstable banks and some sticks and branches are present on the point bar. Ice may also accumulate on the point bar. About 30 feet US there is a small debris pile.

\begin{tabular}{|l|c|c|c|c|c|c|c|c|}
\hline Abutments & $\begin{array}{c}\text { 71. Attack } \\
\angle \text { (BF) }\end{array}$ & $\begin{array}{c}\text { 72. Slope } \angle \\
\text { (Qmax) }\end{array}$ & $\begin{array}{c}\text { 73. Toe } \\
\text { loc. (BF) }\end{array}$ & $\begin{array}{c}\text { 74. Scour } \\
\text { Condition }\end{array}$ & $\begin{array}{c}75 . \text { Scour } \\
\text { depth }\end{array}$ & $\begin{array}{c}\text { 76. Exposure } \\
\text { depth }\end{array}$ & 77. Material & 78. Length \\
\hline LABUT & & $\mathbf{1 0}$ & $\mathbf{9 0}$ & $\mathbf{2}$ & $\mathbf{2}$ & $\mathbf{1}$ & $\mathbf{1}$ & $\mathbf{9 0 . 0}$ \\
\hline RABUT & $\mathbf{1}$ & - & $\mathbf{9 0}$ & & & $\mathbf{0}$ & $\mathbf{0}$ & $\mathbf{2 9 . 5}$ \\
\hline
\end{tabular}

Pushed: $L B$ or RB

Toe Location (Loc.): 0- even, 1- set back, 2- protrudes

Scour cond.: 0- not evident; 1- evident (comment); 2- footing exposed; 3-undermined footing; 4- piling exposed; 5- settled; 6- failed

Materials: 1- Concrete; 2- Stone masonry or drywall; 3- steel or metal; 4- wood

79. Abutment comments (eg. undermined penetration, unusual scour processes, debris, etc.):

0

0

1

The entire length of the left abutment footing is exposed from 1.5 feet at the upstream end to 0.5 feet at the downstream end.

80. Wingwalls:

$\begin{array}{lllll}\text { Exist? Material? } & \text { Scour } & \text { Scour Exposure } & & \\ \text { Angle? Length? } & \text { Condition? depth? } & \text { depth? }\end{array}$

USLWW:

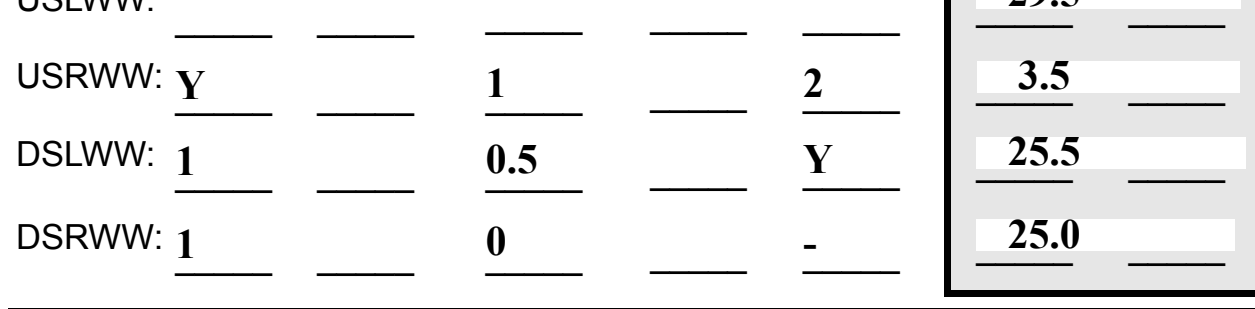

Wingwall materials: 1- Concrete; 2- Stone masonry or drywall; 3- steel or metal; 4- wood

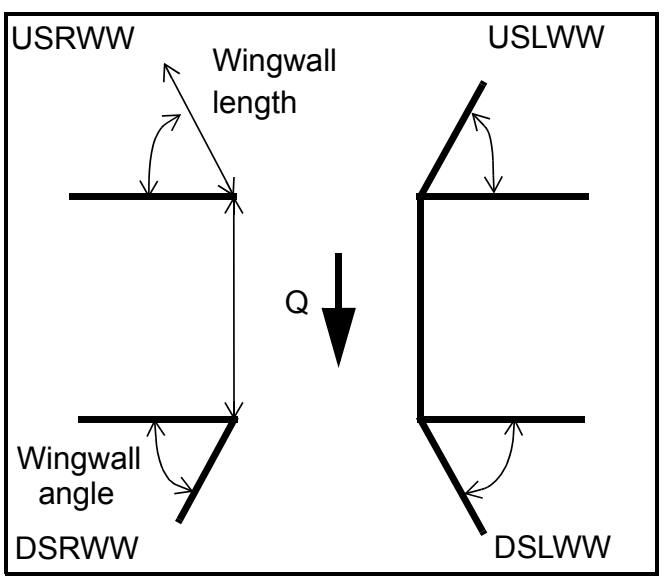

82. Bank / Bridge Protection:

\begin{tabular}{|l|l|l|l|l|l|l|c|c|}
\hline Location & USLWW & USRWW & LABUT & RABUT & LB & RB & DSLWW & DSRWW \\
\hline Type & - & $\mathbf{2}$ & $\mathbf{Y}$ & - & - & - & - & - \\
\hline Condition & $\mathbf{Y}$ & $\mathbf{1}$ & $\mathbf{1}$ & - & - & - & - & - \\
\hline Extent & $\mathbf{1}$ & $\mathbf{0 . 5}$ & $\mathbf{0}$ & $\mathbf{0}$ & $\mathbf{0}$ & $\mathbf{0}$ & $\mathbf{0}$ & - \\
\hline
\end{tabular}

Bank / Bridge protection types: 0- absent; 1- < 12 inches; 2- < 36 inches; 3- < 48 inches; 4- < 60 inches; 
83. Wingwall and protection comments (eg. undermined penetration, unusual scour processes, etc.):

$-$

$-$

$-$

$-$

0

-

0

0

\section{Piers:}

84. Are there piers? Th (Y or if $N$ type ctrl-n pr)

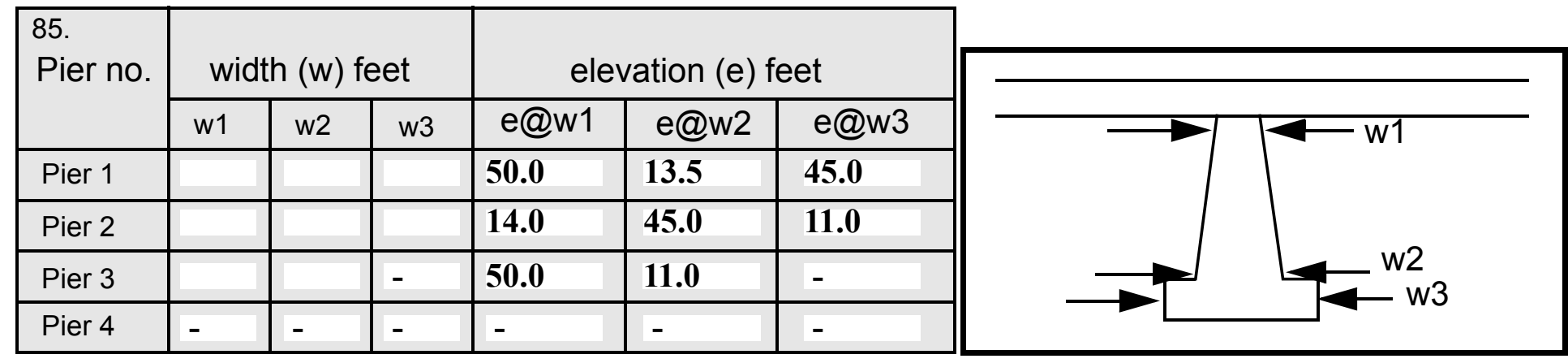

\begin{tabular}{|l|l|l|l|l|}
\hline Level 1 Pier Descr. & \multicolumn{1}{|c|}{1} & \multicolumn{1}{|c|}{2} & 3 & 4 \\
\hline 86. Location (BF) & ere is & any of & & - \\
\hline 87. Type & very & the & & - \\
\hline 88. Material & little & wing & & - \\
\hline 89. Shape & pro- & walls & N & - \\
\hline 90. Inclined? & tec- & - & - & - \\
\hline 91. Attack $\angle$ (BF) & tion & & - & - \\
\hline 92. Pushed & unde & & - & - \\
\hline 93. Length (feet) & - & - & - & - \\
\hline 94. \# of piles & r the & & - & - \\
\hline 95. Cross-members & brid & & - & - \\
\hline 96. Scour Condition & ge or & & - & - \\
\hline 97. Scour depth & alon & & - & - \\
\hline 98. Exposure depth & g & & - & - \\
\hline
\end{tabular}

LFP, LTB, LB, MCL, MCM, MCR, RB, RTB, RFP

1- Solid pier, 2-column, 3- bent

1-Wood; 2- concrete; 3- metal; 4- stone

1- Round; 2- Square; 3- Pointed

Y-yes; $N$ - no

$L B$ or $R B$

0- none; 1- laterals; 2- diagonals; 3- both

0- not evident; 1- evident (comment);

2- footing exposed; 3- piling exposed;

4- undermined footing; 5- settled; 6-failed 
99. Pier comments (eg. undermined penetration, protection and protection extent, unusual scour processes, etc.):

-
-
-
-
-
-
-
-
-
-

100.

\section{E. Downstream Channel Assessment}

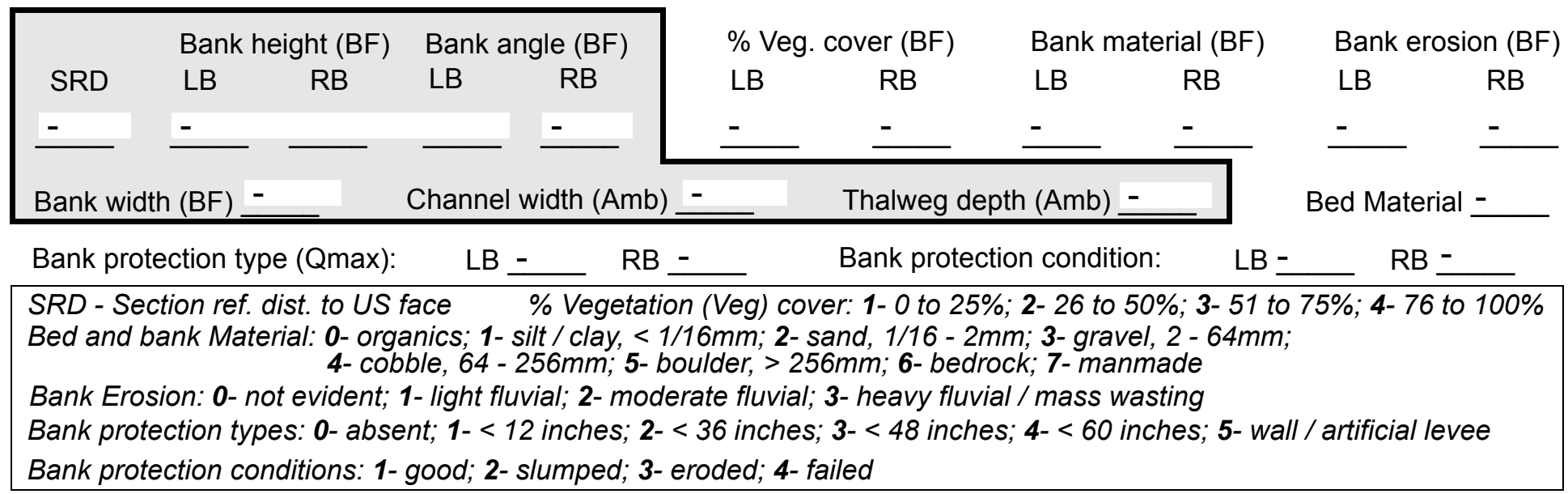

Comments (eg. bank material variation, minor inflows, protection extent, etc.):

-
-
-
-
-
-
-
NO PIERS

101. Is a drop structure present? (Y or $N$, if $N$ type ctrl-n ds)

102. Distance: - feet
103. Drop: - feet
104. Structure material: (1- steel sheet pile; 2- wood pile; 3- concrete; 4- other)

105. Drop structure comments (eg. downstream scour depth):

1

1 
106. Point/Side bar present? $\underline{\mathbf{3 4}}$ (Y or N. if $N$ type ctrl-n pb)Mid-bar distance: $\underline{\mathbf{2}}$ Mid-bar width: $\mathbf{0}$

Point bar extent: 0 feet (US, UB, DS) to feet $\underline{\mathbf{T h}}$ (US, UB, DS) positioned $\underline{\mathbf{e}}$ \%LB to DS \%RB

Material: rea

Point or side bar comments (Circle Point or Side; note additional bars, material variation, status, etc.):

ch makes a slight bend to the left at the downstream point bar. The right bank is cut by stream erosion, which is greatest near the point bar.

Is a cut-bank present? (Y or if $N$ type ctrl-n cb) Where? (LB or $R B)$

Mid-bank distance:

Cut bank extent: feet (US, UB, DS) to feet (US, UB, DS)

Bank damage: (1- eroded and/or creep; 2- slip failure; 3- block failure)

Cut bank comments (eg. additional cut banks, protection condition, etc.):

$\mathbf{N}$

Is channel scour present? _-_ (Y or if $N$ type ctrl-n cs) Mid-scour distance: NO

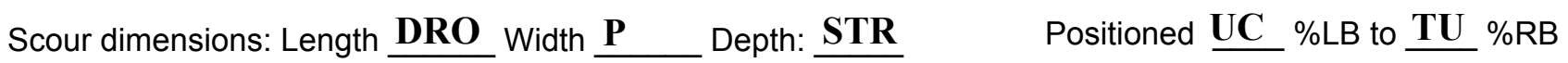
Scour comments (eg. additional scour areas, local scouring process, etc.):

RE

Are there major confluences? ( $Y$ or if $N$ type ctrl-n $m c)$

How many?

Confluence 1: Distance $\underline{\mathbf{Y}}$ Enters on $\underline{48}$ (LB or RB)

Type 14 (1- perennial; 2- ephemeral)

Confluence 2: Distance $\underline{\mathbf{3 6}}$ Enters on $\underline{\text { DS }}(L B$ or $R B)$

Type 80 (1-perennial; 2-ephemeral)

Confluence comments (eg. confluence name):

DS

0

\section{F. Geomorphic Channel Assessment}

107. Stage of reach evolution $\mathbf{5 0}$

1- Constructed

2- Stable

3- Aggraded

4- Degraded

5- Laterally unstable

6- Vertically and laterally unstable 
108. Evolution comments (Channel evolution not considering bridge effects; See HEC-20, Figure 1 for geomorphic descriptors):

342

The point bar is composed of medium to coarse gravel with some cobbles and coarse sand. The bar is not vegetated except along the immediate left bank edge.

$\mathbf{Y}$

RB

55

34

DS

145

DS

3 


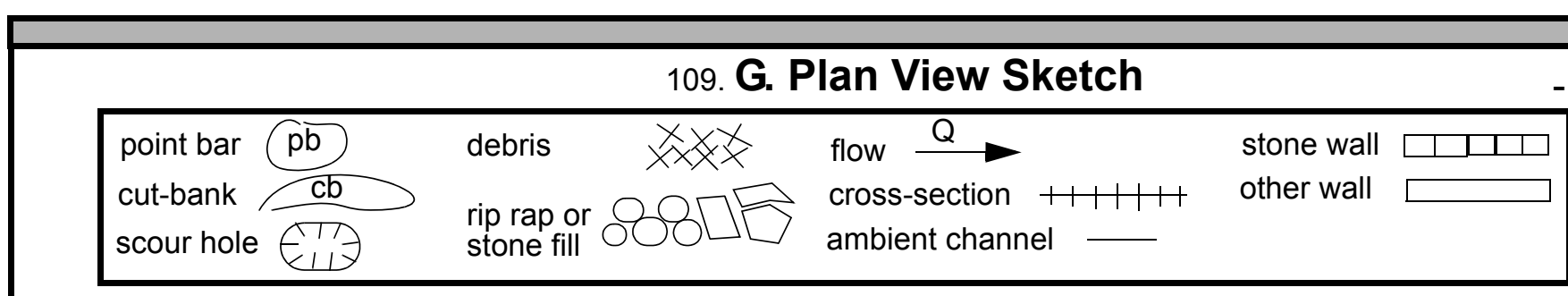

cut-bank $\mathrm{cb}$

scour hole rip rap or
stone fill stone fill cross-section $+1+1+1$ ambient channe other wall 
APPENDIX F:

SCOUR COMPUTATIONS 


$\begin{array}{llll}\begin{array}{l}\text { Structure Number: } \\ \text { Road Number: }\end{array} & \text { TH 2TH00020009 } & \text { Town: } & \text { Lowell } \\ \text { Stream: } & \text { East Branch Missisquoi River } & \text { Orleans } \\ & \text { Date: } & 5 / 12 / 97 \quad \text { Checked: RF } & 6 / 18 / 97\end{array}$

Analysis of contraction scour, live-bed or clear water?

Critical Velocity of Bed Material (converted to English units)

$\mathrm{VC}=11.21{ }^{*} \mathrm{Y} 1^{\wedge} 0.1667 * \mathrm{D} 50^{\wedge} 0.33$ with $\mathrm{Ss}=2.65$

(Richardson and others, 1995, p. 28, eq. 16)

Approach section

Characteristic

Total discharge, cfs

Main Channel Area, ft2

Left overbank area, ft2

Right overbank area, ft2

Top width main channel, ft

Top width L overbank, ft

Top width $\mathrm{R}$ overbank, ft

D50 of channel, ft

D50 left overbank, ft

D50 right overbank, ft

Y1, average depth, MC, ft

y1, average depth, LOB, ft

Y1, average depth, ROB, ft

Total conveyance, approach

Conveyance, main channel

Conveyance, LOB

Conveyance, ROB

Percent discrepancy, conveyance

Qm, discharge, MC, cfs

Ql, discharge, LOB, Cfs

Qr, discharge, ROB, cfs

$\mathrm{Vm}$, mean velocity $\mathrm{MC}$, ft/s

$\mathrm{Vl}$, mean velocity, LOB, ft/s

Vr, mean velocity, ROB, ft/s

Vc-m, crit. velocity, MC, ft/s

Vc-l, crit. velocity, LOB, ft/s

Vc-r, crit. velocity, ROB, ft/s

Results

Live-bed(1) or Clear-Water(0) Contraction Scour? Main Channel

\begin{tabular}{|c|c|c|}
\hline $100 \mathrm{yr}$ & $500 \mathrm{yr}$ & other $Q$ \\
\hline 2000 & 2770 & 1880 \\
\hline 361 & 390 & 346 \\
\hline 59 & 134 & 0 \\
\hline 1700 & 1887 & 1601 \\
\hline 46 & 46 & 45 \\
\hline 114 & 117 & 0 \\
\hline 291 & 291 & 291 \\
\hline 0.109 & 0.109 & 0.109 \\
\hline-- & -- & -- \\
\hline-- & -- & -- \\
\hline 7.8 & 8.5 & 7.7 \\
\hline 0.5 & 1.1 & ERR \\
\hline 5.8 & 6.5 & 5.5 \\
\hline 138840 & 166766 & 125583 \\
\hline 36131 & 41030 & 33874 \\
\hline 1425 & 5439 & 0 \\
\hline 101284 & 120298 & 91710 \\
\hline 0.0000 & -0.0006 & -0.0008 \\
\hline 520.5 & 681.5 & 507.1 \\
\hline 20.5 & 90.3 & 0.0 \\
\hline 1459.0 & 1998.2 & 1372.9 \\
\hline 1.4 & 1.7 & 1.5 \\
\hline 0.3 & 0.7 & ERR \\
\hline 0.9 & 1.1 & 0.9 \\
\hline 7.5 & 7.6 & 7.5 \\
\hline ERR & ERR & ERR \\
\hline ERR & ERR & ERR \\
\hline
\end{tabular}

0

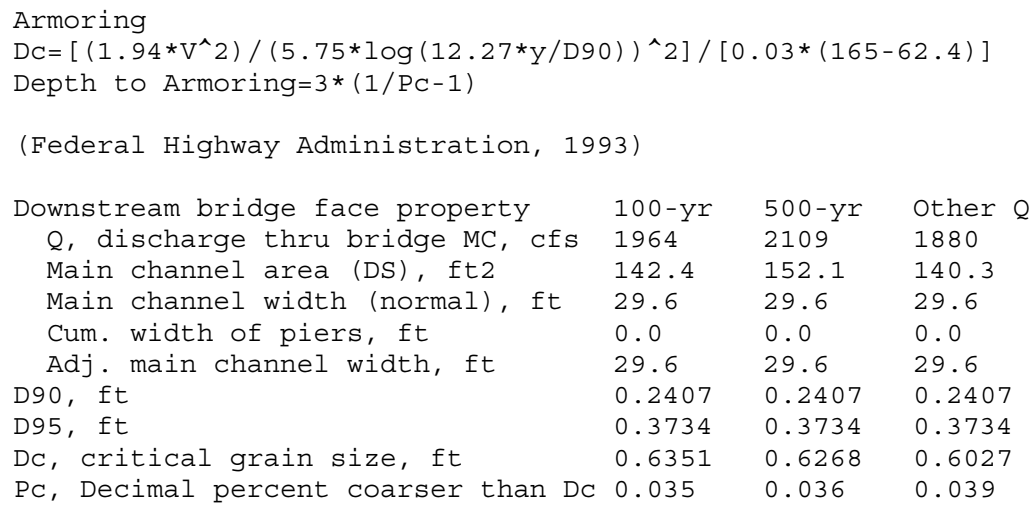

Depth to armoring, ft N/A N/A N N A 
Clear water Contraction Scour in MAIN CHANNEL

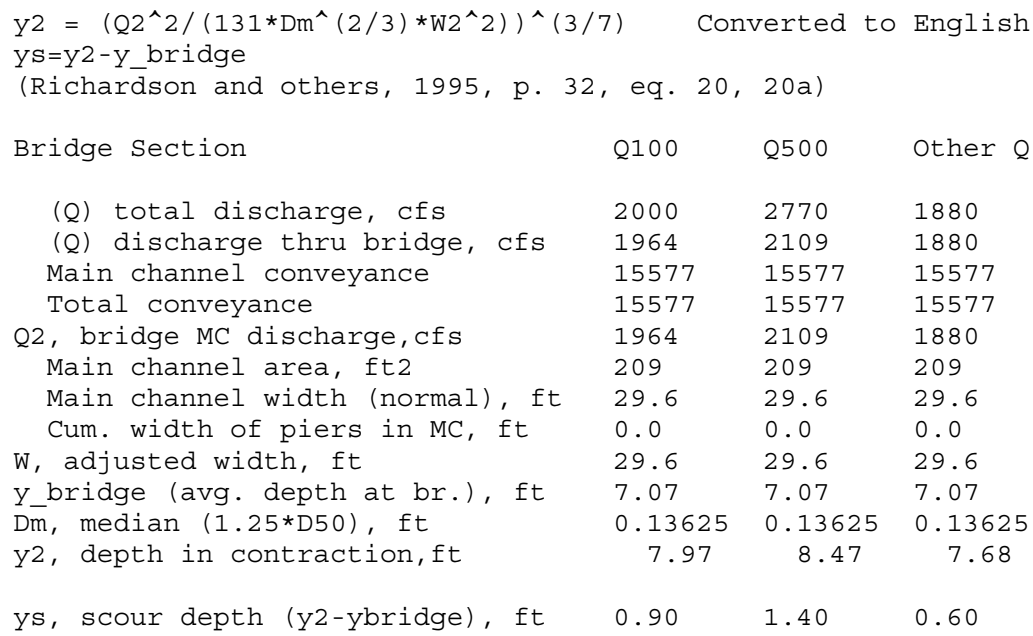

Pressure Flow Scour (contraction scour for orifice flow conditions)

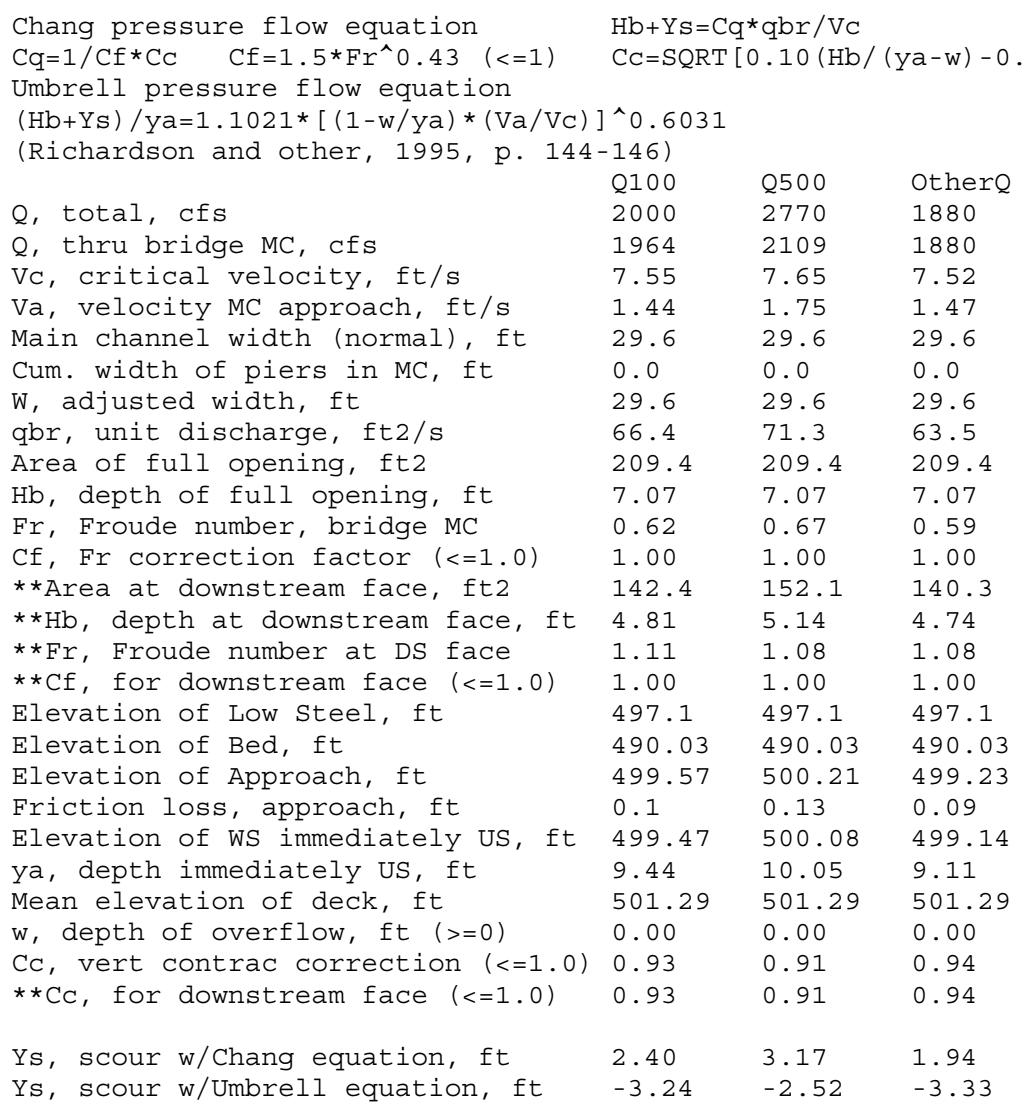

**=for UNsubmerged orifice flow using estimated downstream bridge face properties.

**Ys, scour w/Chang equation, ft $4.64 \quad 5.10 \quad 4.24$

**Ys, scour w/Umbrell equation, ft $\begin{array}{llll}-0.98 & -0.59 & -0.99\end{array}$

In UNsubmerged orifice flow, an adjusted scour depth using the Laursen equation results and the estimated downstream bridge face properties can also be computed (ys=y2-ybridgeDs)

$\begin{array}{llll}\text { Y2, from Laursen's equation, ft } & 7.97 & 8.47 & 7.68 \\ \text { WSEL at downstream face, ft } & 494.83 & 495.16 & 494.76 \\ \text { Depth at downstream face, ft } & 4.81 & 5.14 & 4.74 \\ \text { depth of scour (Laursen) ft } & 3.16 & 3.33 & 2.94\end{array}$

Ys, depth of scour (Laursen), ft $3.16 \quad 3.33 \quad 2.94$ 
Abutment Scour

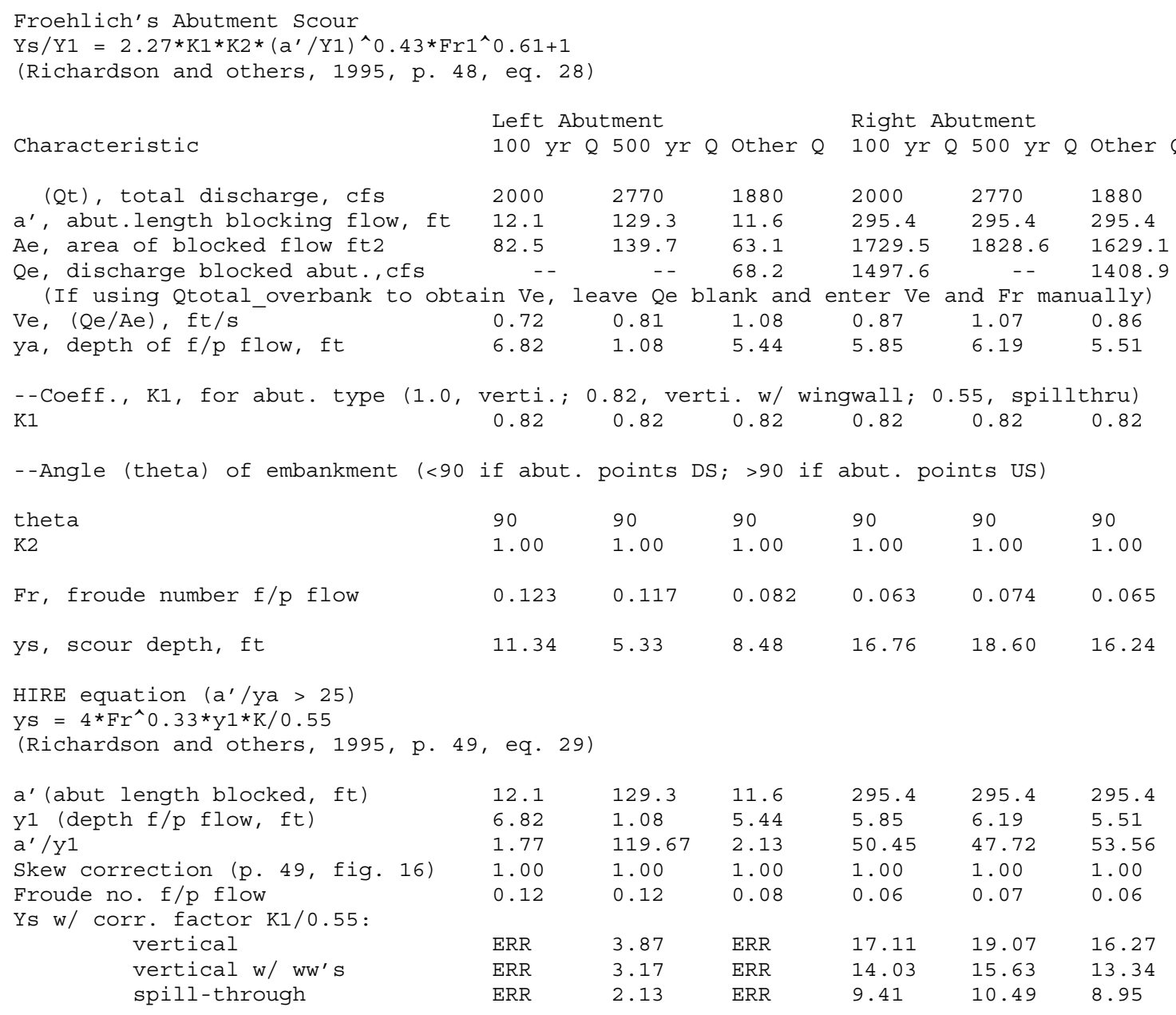

Abutment riprap sizing

Isbash Relationship

$\mathrm{D} 50=\mathrm{Y} * \mathrm{~K} * \mathrm{Fr} \wedge 2 /(\mathrm{Ss}-1)$ and $\mathrm{D} 50=\mathrm{Y} * \mathrm{~K} *\left(\mathrm{Fr} r^{\wedge} 2\right)^{\wedge} 0.14 /(\mathrm{Ss}-1)$

(Richardson and others, 1995, p112, eq. 81,82)

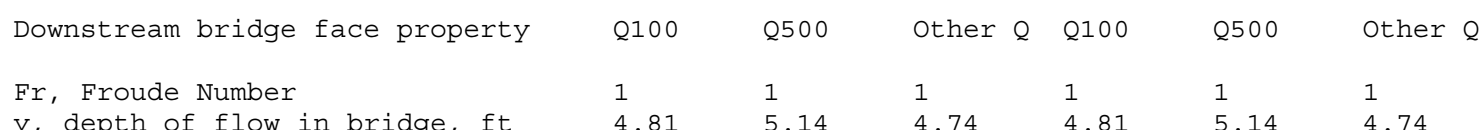

Median Stone Diameter for riprap at: left abutment right abutment, ft

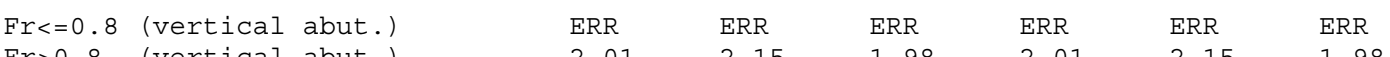

$\begin{array}{llllllll}\text { Fr }>0.8 & \text { (vertical abut.) } & 2.01 & 2.15 & 1.98 & 2.01 & 2.15 & 1.98\end{array}$

